\title{
Use of Tunable Ligands Allows for Intermolecular Pd-Catalyzed C-O Bond Formation
}

\author{
Andrei V. Vorogushin, Xiaohua Huang, Stephen L. Buchwald* \\ Department of Chemistry \\ Massachusetts Institute of Technology \\ Cambridge, MA 02139
}

Supporting Information.

General Considerations. All ligand syntheses and Pd-catalyzed cross-coupling reactions were carried out under an atmosphere of argon in oven-dried glassware. Unless otherwise indicated, all other reactions were carried out under an atmosphere of argon. Toluene, THF, and diethyl ether were purchased from J. T. Baker in CYCLE-TAINER ${ }^{\circledR}$ solvent delivery kegs, which were vigorously purged with argon for $2 \mathrm{~h}$, and further purified by passing the solvent through two packed columns of neutral alumina and copper (II) oxide under argon pressure. Silica gel chromatography purifications were performed by flash chromatography using EM Science silica gel 60 (230-400 mesh). Tributylamine was distilled over $\mathrm{CaH}_{2}$ and stored under argon. 1-Butanol, 2-butanol, benzyl alcohol were purchased from Aldrich in Sure-Seal ${ }^{\circledR}$ bottles and used without further purification. All other alcohols were purchased from Alfa Aesar or Aldrich, dried by stirring with $\mathrm{CaH}_{2}$, filtered through a layer of Celite and stored under argon over $3 \AA$ molecular sieves. Ditert-butylchlorophosphine was generously donated by FMC Lithium and distilled before use. Liquid aryl halides were purchased from Alfa Aesar or Aldrich and filtered through a thin pad of alumina prior to use. Magnesium powder (50 mesh) was purchased from Aldrich and used without further purification. A solution of neopentylmagnesium 
chloride was purchased from Alfa Aesar. Anhydrous $\mathrm{Cs}_{2} \mathrm{CO}_{3}$ was generously donated by Chemetall $\mathrm{GmbH}$; the bulk of the material was stored under nitrogen in a Vacuum Atmospheres glovebox. Small portions (1-2 g) were removed from the glovebox in glass vials, stored in the air in desiccators filled with anhydrous calcium sulfate, and weighed in the air. $\mathrm{Pd}(\mathrm{OAc})_{2}$, copper (I) chloride, $\mathrm{ZnCl}_{2}$ and bromine were purchased from Strem chemical company and used without further purification. 1,2,3,4-Tetramethylbenzene was purchased from TCI America, Inc. GC yields (Table 1) were determined using dodecane as an internal standard. Yields refer to isolated yields of compounds greater than $95 \%$ purity as determined by capillary gas chromatography (GC), and proton Nuclear Magentic Resonance spectroscopy ( ${ }^{1} \mathrm{H}$ NMR) analysis. New compounds were also characterized by elemental analysis (Atlantic Microlabs, Norcross, GA). Yields reported in this section refer to a single experiment whereas those reported for Pdcatalyzed coupling of aryl halides with alcohols are an average of two runs. IR spectra were recorded on a Perkin Elmer system 2000 FT-IR. Specific rotations were measured on a Jasco P-1010 polarimeter. Mass spectra were recorded on Bruker Apex IV FT-MS with 4.7 T magnet and EI or ESI ion source. ${ }^{1} \mathrm{H}$ NMR, ${ }^{13} \mathrm{C}$ NMR, ${ }^{31} \mathrm{P}$ NMR spectra were recorded on Varian $300 \mathrm{MHz}$, Varian $500 \mathrm{MHz}$ or Bruker $400 \mathrm{MHz}$ instruments with chemical shifts reported in ppm relative to the residual deuterated solvent or TMS as an internal standard. Gas chromatography analyses were performed on a Hewlett Packard 6890 instrument with a FID detector and a Hewlett Packard 10 m x $0.1 \mathrm{~mm}$ i.d. HP-1 column. Melting points (uncorrected) were obtained on a Mel-Temp capillary melting 
point apparatus. The procedures described in this section are representative; thus, the yields may differ slightly from those given in Tables 1,2, 3 and eq. 2.

\section{Synthesis of Ligands.}

Ligands $\mathbf{L 1},{ }^{1} \mathbf{L 2},{ }^{2} \mathbf{L 3},{ }^{3} \mathbf{L 5}^{4}$ have been previously reported by our group.

\section{1,2-Dibromo-3,4,5,6-tetramethylbenzene.}

The reaction was performed using a modification of the known procedure. ${ }^{5} \mathrm{ZnCl}_{2}(23.12$ $\mathrm{g}, 170 \mathrm{mmol})$ was added to a solution of 1,2,3,4-tetramethylbenzene (10.72 $\mathrm{g}, 80 \mathrm{mmol})$ in acetic acid $(320 \mathrm{~mL})$. To the above solution was added bromine $(26.90 \mathrm{~g}, 8.8 \mathrm{~mL}, 168$ mmol) dropwise, at room temperature. After the addition was complete the formation of a white precipitate was observed. The reaction mixture was stirred for $14 \mathrm{~h}$ at room temperature, then a saturated solution of $\mathrm{Na}_{2} \mathrm{SO}_{3}(50 \mathrm{~mL})$ was added to quench the excess of bromine. $\mathrm{CH}_{2} \mathrm{Cl}_{2}(400 \mathrm{~mL})$ and water $(400 \mathrm{~mL})$ were added to the resulting colorless mixture and stirring was continued for $30 \mathrm{~min}$ at room temperature until the white precipitate dissolved. The mixture was transferred to a separatory funnel. The organic layer was collected, washed with $10 \%$ aqueous $\mathrm{NaOH}(3 \times 200 \mathrm{~mL})$ and water $(200 \mathrm{~mL})$. The organic layer was separated, dried over $\mathrm{MgSO}_{4}$ and concentrated in vacuo to afford crude product. Crystallization was performed by dissolving the compound in THF and adding hexane $(50 \mathrm{~mL})$. Cooling the solution to $0{ }^{\circ} \mathrm{C}$ resulted in the formation of a white solid, which was washed with pentane and dried. Two crops were collected. Combined 
yield of the title compound: 19.96 g, 85 \%. M.p. $204-206^{\circ} \mathrm{C}$ (lit. $\left.{ }^{6} 208{ }^{\circ} \mathrm{C}\right) .{ }^{1} \mathrm{H}$ NMR (300 $\left.\mathrm{MHz}, \mathrm{CDCl}_{3}\right) \delta 2.50(\mathrm{~s}, 6 \mathrm{H}), 2.25(\mathrm{~s}, 6 \mathrm{H})$.

\section{Synthesis of Ligands. General procedure.}

An oven-dried Schlenk tube was charged with magnesium powder $(0.280 \mathrm{~g}, 11.5 \mathrm{mmol})$, aryl bromide $(5.0 \mathrm{mmol})$ and THF $(6 \mathrm{~mL})$. The Schlenk tube was put into a $60{ }^{\circ} \mathrm{C}$ oil bath and 1,2-dibromoethane (43 $\mathrm{mg}, 20 \mu 1,0.23 \mathrm{mmol}$ ) was added dropwise via syringe over $15 \mathrm{~min}$. The mixture was stirred at $60{ }^{\circ} \mathrm{C}$ for $15 \mathrm{~min}$ and then 1,2 -dibromo-3,4,5,6tetramethylbenzene $(1.46 \mathrm{~g}, 5.00 \mathrm{mmol})$ was added portionwise over $30 \mathrm{~min}$. The resulting mixture was stirred at $60{ }^{\circ} \mathrm{C}$ for $1.5 \mathrm{~h}$, and then allowed to cool to room temperature. Copper(I) chloride $(0.50 \mathrm{~g}, 5.0 \mathrm{mmol})$ was weighed in the glovebox and removed from the glovebox right before its addition into the above reaction mixture under a flow of argon. This was followed by the addition of di-tert-butylchlorophosphine $(1.083 \mathrm{~g}, 1.2 \mathrm{~mL}, 6.0 \mathrm{mmol})$. The Schlenk tube was sealed with a Teflon screw cap and put into a $75^{\circ} \mathrm{C}$ oil bath. The reaction mixture was stirred at $75^{\circ} \mathrm{C}$ for $40 \mathrm{~h}$. The Schlenk tube was taken out of the $75{ }^{\circ} \mathrm{C}$ oil bath and allowed to cool to room temperature. The reaction mixture was quenched with $30 \%$ aqueous $\mathrm{NH}_{4} \mathrm{OH}$ solution $(50 \mathrm{~mL})$. The resulting suspension was extracted with $4: 1$ ethyl acetate : diethyl ether $(100 \mathrm{~mL})$. The organic layer was separated and washed with $30 \%$ aqueous $\mathrm{NH}_{4} \mathrm{OH}(3 \times 50 \mathrm{~mL})$ and brine once $(50 \mathrm{~mL})$, dried over $\mathrm{MgSO}_{4}$, filtered and concentrated in vacuo. The product was purified as indicated below. 


\section{2-Di-tert-butylphosphino-3,4,5,6-tetramethyl-2',4',6'-tri-iso-propylbiphenyl (L4).}

The general procedure for ligand synthesis was followed. The product was crystallized from a mixture of ethanol and methyl iso-propyl ketone to give $1.214 \mathrm{~g}$ of the title compound as a white crystalline solid. The solvent was removed from the filtrate in vacuo and the residue was crystallized from ethanol to give $0.320 \mathrm{~g}$ of the title compound. Combined yield 1.534 g (64 \%). Colorless crystals. M.p. $162-163{ }^{\circ} \mathrm{C} .{ }^{1} \mathrm{H}$ NMR (300 MHz, $\left.\mathrm{C}_{6} \mathrm{D}_{6}\right) \delta 7.19(\mathrm{~s}, 2 \mathrm{H}), 2.86$ (septet, $\left.\mathrm{J}=6.9 \mathrm{~Hz}, 1 \mathrm{H}\right), 2.72$ (septet, J = 6.6 Hz, 2H), 2.47 (s, 3H), 2.02 (s, 3H), 1.98 (s, 3H), 1.87 (s, 3H), 1.41 (d, J = 6.6 Hz, 6H), $1.26(\mathrm{~d}, \mathrm{~J}=6.9 \mathrm{~Hz}, 6 \mathrm{H}), 1.20\left(\mathrm{~d}, \mathrm{~J}_{\mathrm{HP}}=12.0 \mathrm{~Hz}, 18 \mathrm{H}\right), 1.06(\mathrm{~d}, \mathrm{~J}=6.9 \mathrm{~Hz}, 6 \mathrm{H}) .{ }^{13} \mathrm{C} \mathrm{NMR}$ $\left(75 \mathrm{MHz}, \mathrm{C}_{6} \mathrm{D}_{6}\right) \delta 148.7,148.2,148.1,147.2,147.1,139.92,139.87,139.6,139.5$ $137.06,137.04,135.5,134.9,134.8,134.7,134.1,121.3,35.1,34.9,34.6,33.3,33.0$ $31.8,31.7,27.30,27.28,26.0,25.21,25.18,24.8,22.4,22.3,17.4,17.3$ (observed

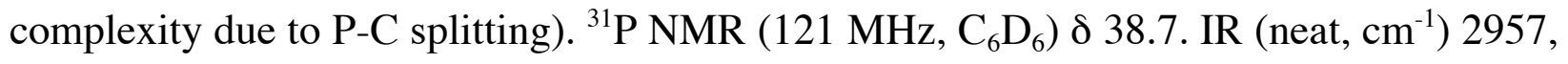
1459, 1382, 1361, 1067, 875, 802, 742. Anal. Calcd for $\mathrm{C}_{33} \mathrm{H}_{53} \mathrm{P}: \mathrm{C}, 82.45 ; \mathrm{H}, 11.11$. Found: C, 82.27; H, 11.11 .

\section{1-(2-Di-tert-butylphosphino-3,4,5,6-tetramethylphenyl)-2-iso-propylnaphthalene} (L6).

Step 1. 1-Bromo-2-iso-propylnaphthalene (99\% isomeric purity). 
Bromination of 2-iso-propylnaphthalene was carried out according to the known procedure. $^{7}$ A $100 \mathrm{~mL}$ round-bottom flask was charged with 2-iso-propylnaphthalene (11.3 g, $66.5 \mathrm{mmol})$ and $\mathrm{CS}_{2}(20 \mathrm{~mL})$. To the resulting solution, bromine $(11.7 \mathrm{~g}, 73$ mmol, $3.76 \mathrm{~mL}$ ) was added dropwise with stirring. After the addition was complete, the mixture was stirred at room temperature for $17 \mathrm{~h}$, then the excess of bromine was quenched by the addition of saturated aqueous $\mathrm{Na}_{2} \mathrm{SO}_{3}$ solution $(25 \mathrm{~mL})$. Water $(50 \mathrm{~mL})$ was added and the mixture was transferred to a separatory funnel. The organic layer was isolated and the aqueous layer was further extracted with diethyl ether $(2 \times 25 \mathrm{~mL})$. The combined organic extracts were dried over $\mathrm{MgSO}_{4}$. The solvent was removed and the residue was distilled in vacuo to give $14.99 \mathrm{~g}$ of yellowish liquid, which was analyzed by GC. Composition of the mixture: 2-iso-propylnaphthalene (2\%), 1-bromo-2-isopropylnaphthalene $(87 \%)$, isomeric bromo-2-iso-propylnaphthalenes $(11 \%)$. The isomeric purity of 1-bromo-2-iso-propylnaphthalene was improved using a $\mathrm{Ni}$-catalyzed Kumada coupling procedure. ${ }^{8}$ The above mixture was dissolved in diethyl ether $(3.4 \mathrm{~mL})$. $\mathrm{NiCl}_{2}\left(\mathrm{PPh}_{3}\right)_{2}(235 \mathrm{mg}, 0.36 \mathrm{mmol})$ was added to the solution and the mixture was cooled to $0{ }^{\circ} \mathrm{C}$. Next, $\mathrm{MeMgBr}(3 \mathrm{M}, 18 \mathrm{mmol}, 6 \mathrm{~mL})$ was added dropwise. When the addition was complete the reaction mixture was heated to reflux for $12 \mathrm{~h}$, then cooled to room temperature and quenched by the dropwise addition of $10 \% \mathrm{HCl}(3.5 \mathrm{~mL})$. The resulting mixture was transferred to a separatory funnel and shaken with $10 \% \mathrm{HCl}(70 \mathrm{~mL})$. The organic layer was separated and the aqueous layer was back extracted with diethyl ether ( $2 \times 25 \mathrm{~mL})$. The combined organic layers were dried over $\mathrm{MgSO}_{4}$, the solvent was removed and the residue was filtered through a plug of silica gel (hexane) to give, after 
evaporation of the solvent, $13.73 \mathrm{~g}$ of a colorless oil. The product mixture was analyzed by GC and ${ }^{1} \mathrm{H}$ NMR and found to consist of 1-bromo-2-iso-propylnaphthalene (99\% isomeric purity, $\sim 75 \%$ of the mixture), 2-iso-propylnaphthalene and isomeric methyl-2iso-propylnaphthalenes. The yield of 1-bromo-2-iso-propylnaphthalene was approximately $62 \%$. The mixture was used in the next step without further purification.

\section{Step 2. 1-(2-Di-tert-butylphosphino-3,4,5,6-tetramethylphenyl)-2-iso- propylnaphthalene.}

An oven-dried two-neck $250 \mathrm{~mL}$ round-bottom flask was charged with magnesium powder (2.256 g, $94 \mathrm{mmol})$, 1-bromo-2-iso-propylnaphthalene (13.722 $\mathrm{g}$ of the mixture, step 1) and THF (50 mL). One neck was fitted with a rubber septum and another equipped with a pressure-equalizing dropping funnel. The dropping funnel was charged with 1,2-dibromo-3,4,5,6-tetramethylbenzene (13.14 g, $45 \mathrm{mmol})$ and diethyl ether (50 $\mathrm{mL}$ ) and equipped with a reflux condenser. The apparatus was flushed with argon and the flask was put into a $60{ }^{\circ} \mathrm{C}$ oil bath and 1,2-dibromoethane $(107 \mathrm{mg}, 50 \mu \mathrm{L}, 0.57 \mathrm{mmol})$ was added dropwise via syringe over $15 \mathrm{~min}$. The mixture was stirred at $60{ }^{\circ} \mathrm{C}$ for an additional $15 \mathrm{~min}$. Then the temperature of the oil bath was raised to $65{ }^{\circ} \mathrm{C}$ and the stopcock of the dropping funnel was opened. Throughout the addition of 1,2-dibromo3,4,5,6-tetramethylbenzene $(\sim 4 \mathrm{~h})$ the level of diethyl ether in the dropping funnel was kept constant by adjusting the stopcock. After the addition was complete the stopcock was closed and the reaction mixture was stirred at $65{ }^{\circ} \mathrm{C}$ for $1 \mathrm{~h}$. Diethyl ether was distilled out of the reaction flask and collected in the dropping funnel. THF (30 mL) was 
added into the flask and the hot solution was transferred via cannula into a $200 \mathrm{~mL}$ Schlenk tube, which contained copper(I) chloride (4.059 g, $41 \mathrm{mmol})$ under argon, followed by the addition of di-tert-butylchlorophosphine $(8.88 \mathrm{~g}, 9.84 \mathrm{~mL}, 49 \mathrm{mmol})$ into the reaction mixture. The Schlenk tube was sealed with a Teflon screw cap and put into a $75{ }^{\circ} \mathrm{C}$ oil bath. The reaction mixture was stirred at $75^{\circ} \mathrm{C}$ for $48 \mathrm{~h}$. The Schlenk tube was taken out of the $75{ }^{\circ} \mathrm{C}$ oil bath and allowed to cool to room temperature. The reaction mixture was quenched with $30 \%$ aqueous $\mathrm{NH}_{4} \mathrm{OH}$ solution $(400 \mathrm{~mL}$, first $30 \mathrm{~mL}$ dropwise, with stirring). The resulting suspension was extracted with $4: 1$ ethyl acetate : diethyl ether $(800 \mathrm{~mL})$. The organic layer was separated and washed with $30 \%$ aqueous $\mathrm{NH}_{4} \mathrm{OH}(3 \times 200 \mathrm{~mL})$, then phosphines were extracted into the aqueous layer by $10 \%$ $\mathrm{HCl}(2 \times 400 \mathrm{~mL})$. The combined organic layers were basified by the addition of $10 \%$ $\mathrm{NaOH}$. The crude product precipitated as yellow solid. It was filtered, washed with water, then with $4: 1$ ethyl acetate : diethyl ether $(200 \mathrm{~mL})$. The filtrate was transferred into a separatory funnel and shaken. The organic layer was isolated and the aqueous layer was extracted with $4: 1$ ethyl acetate : diethyl ether $(200 \mathrm{~mL})$. The combined organic extracts were dried over $\mathrm{MgSO}_{4}$, the solvent was removed and the residue was combined with the previously isolated solid. This mixture was recrystallized from methyl iso-propyl ketone to give a white solid, which was washed with methanol. The mother liquor was concentrated and filtered through a plug of silica gel (25\% ethyl acetate in hexane). Two additional crops of crystals were collected and the combined product was dried in vacuo. The yield of the title compound was $13.32 \mathrm{~g}$ (73\%). Colorless crystals. M.p. 165 - 167 ${ }^{\circ} \mathrm{C} .{ }^{1} \mathrm{H}$ NMR $\left(400 \mathrm{MHz}, \mathrm{C}_{6} \mathrm{D}_{6}\right) \delta 7.75(\mathrm{~d}, 1 \mathrm{H}, \mathrm{J}=8.6 \mathrm{~Hz}), 7.71(\mathrm{~d}, 1 \mathrm{H}, \mathrm{J}=8.2 \mathrm{~Hz}), 7.51$ 
$(\mathrm{d}, 1 \mathrm{H}, \mathrm{J}=8.6 \mathrm{~Hz}), 7.19-7.26(\mathrm{~m}, 2 \mathrm{H}), 7.05-7.10(\mathrm{~m}, 1 \mathrm{H}), 3.25($ septet, $1 \mathrm{H}, \mathrm{J}=6.9 \mathrm{~Hz})$

$2.52(\mathrm{~s}, 3 \mathrm{H}), 2.13(\mathrm{~s}, 3 \mathrm{H}), 2.07$ (s, 3H), $1.77(\mathrm{~s}, 3 \mathrm{H}), 1.55(\mathrm{~d}, 3 \mathrm{H}, \mathrm{J}=7.0 \mathrm{~Hz}), 1.32(\mathrm{~d}, 9 \mathrm{H}$,

$\left.\mathrm{J}_{\mathrm{HP}}=11.7 \mathrm{~Hz}\right), 1.05(\mathrm{~d}, 3 \mathrm{H}, \mathrm{J}=7.0 \mathrm{~Hz}), 0.87\left(\mathrm{~d}, 9 \mathrm{H}, \mathrm{J}_{\mathrm{HP}}=11.7 \mathrm{~Hz}\right) \cdot{ }^{13} \mathrm{C} \mathrm{NMR}(100$

$\left.\mathrm{MHz}, \mathrm{C}_{6} \mathrm{D}_{6}\right) \delta 143.10,143.06,139.91,139.87,137.4,135.12,135.10,134.42,134.40$,

$133.0,129.2,128.5,128.3,125.2,125.0,124.2,35.1,34.7,34.0,33.6,33.2,33.0,32.9$,

$32.7,31.74,31.71,27.1,24.5,23.8,20.4,20.3,17.6,17.5$ (observed complexity due to P-

C splitting). ${ }^{31} \mathrm{P}$ NMR (161 MHz, $\left.\mathrm{C}_{6} \mathrm{D}_{6}\right)$ $\delta$ 38.7. IR (neat, $\mathrm{cm}^{-1}$ ) 2959, 1461, 1386, 1360,

1166, 816, 748. Anal. Calcd for $\mathrm{C}_{31} \mathrm{H}_{43} \mathrm{P}$ : C, 83.36; H, 9.70. Found: C, 83.15; H, 9.68.

\section{1-(2-Di-tert-butylphosphinophenyl)-2-iso-propylnaphthalene (L5).}

The reaction was performed using a modification of the known procedure. ${ }^{4}$ An ovendried Schlenk tube was charged with magnesium powder (0.312 g, $13.0 \mathrm{mmol}), 1$-bromo2-iso-propylnaphthalene (99\% isomeric purity, from L6, step 1) (1.705 g of the mixture, $\sim 1.245 \mathrm{~g}, \sim 5.0 \mathrm{mmol})$ and THF $(6 \mathrm{~mL})$. The Schlenk tube was put into a $60{ }^{\circ} \mathrm{C}$ oil bath and 1,2-dibromoethane (43 mg, $20 \mu 1,0.23 \mathrm{mmol}$ ) was added dropwise via syringe over $15 \mathrm{~min}$. The mixture was stirred at $60{ }^{\circ} \mathrm{C}$ for $15 \mathrm{~min}$ and then the solution of 1-bromo-2chlorobenzene (1.245 g, $6.5 \mathrm{mmol})$ in THF $(9 \mathrm{~mL})$ was added over $3.5 \mathrm{~h}$ via syringe with the help of a syringe pump. The resulting mixture was stirred at $60{ }^{\circ} \mathrm{C}$ for $1 \mathrm{~h}$, and then allowed to cool to room temperature. Copper(I) chloride $(0.50 \mathrm{~g}, 5.0 \mathrm{mmol})$ was weighed in the glovebox and removed from the glovebox right before its addition into the above reaction mixture under a flow of argon. This was followed by the addition of di-tertbutylchlorophosphine $(1.083 \mathrm{~g}, 1.2 \mathrm{~mL}, 6.0 \mathrm{mmol})$. The Schlenk tube was sealed with a 
Teflon screw cap and put into a $75{ }^{\circ} \mathrm{C}$ oil bath. The reaction mixture was stirred at $75{ }^{\circ} \mathrm{C}$ for $40 \mathrm{~h}$. The Schlenk tube was taken out of the $75^{\circ} \mathrm{C}$ oil bath and allowed to cool to room temperature. The reaction mixture was quenched with $30 \%$ aqueous $\mathrm{NH}_{4} \mathrm{OH}$ solution $(50 \mathrm{~mL})$. The resulting suspension was extracted with $4: 1$ ethyl acetate : diethyl ether $(100 \mathrm{~mL})$. The organic layer was separated and washed with $30 \%$ aqueous $\mathrm{NH}_{4} \mathrm{OH}$ $(3 \times 50 \mathrm{~mL})$, then phosphines were extracted into the aqueous layer by $10 \% \mathrm{HCl}(2 \times 50$ $\mathrm{mL}$ ). The combined organic layers were basified by the addition of $10 \% \mathrm{NaOH}$. The product was extracted with $4: 1$ ethyl acetate : diethyl ether $(2 \times 50 \mathrm{~mL})$. The combined organic extracts were dried over $\mathrm{MgSO}_{4}$, the solvent was removed to give the crude product as a colorless solid, which was recrystallized from ethanol. Two crops were collected, the combined product was dried in vacuo. The yield of the title compound was 1.186 g $(61 \%)$. Colorless crystals. M.p. $147-149{ }^{\circ} \mathrm{C}\left(\right.$ lit. $\left.{ }^{4} 141-142{ }^{\circ} \mathrm{C}\right) .{ }^{1} \mathrm{H}$ and ${ }^{31} \mathrm{P}$ NMR data were consistent with those of the previously reported compound.

\section{1-(2-Di-tert-butylphosphino-3,4,5,6-tetramethylphenyl)-2-methoxynaphthalene (L7).}

The general procedure for ligand synthesis was followed. The crude product was purified chromatographically (silica gel). First, a mixture of side products was washed out with 10 $\%$ ethyl acetate in hexane. Then the product phosphine was eluted with pure ethyl acetate. The solvent was evaporated and the residue was crystallized from methyl iso-propyl ketone, dried in vacuo to give $0.310 \mathrm{~g}$ of the title compound (14\%). Yellowish crystals. M.p. 208 - $210{ }^{\circ} \mathrm{C} .{ }^{1} \mathrm{H}$ NMR (400 MHz, $\left.\mathrm{C}_{6} \mathrm{D}_{6}\right) \delta$ 7.68-7.75 (m, 2H), 7.40-7.45 (m, 1H), 7.14-7.22 (m, 2H), $7.00(\mathrm{~d}, 1 \mathrm{H}, \mathrm{J}=8.8 \mathrm{~Hz}), 3.38(\mathrm{~s}, 3 \mathrm{H}), 2.55(\mathrm{~s}, 3 \mathrm{H}), 2.14(\mathrm{~s}, 3 \mathrm{H}), 2.05$ 
$(\mathrm{s}, 3 \mathrm{H}), 1.93(\mathrm{~s}, 3 \mathrm{H}), 1.28\left(\mathrm{~d}, 9 \mathrm{H}, \mathrm{J}_{\mathrm{HP}}=12.2 \mathrm{~Hz}\right), 1.02\left(\mathrm{~d}, 9 \mathrm{H}, \mathrm{J}_{\mathrm{HP}}=12.2 \mathrm{~Hz}\right) .{ }^{13} \mathrm{C} \mathrm{NMR}$ $\left(125 \mathrm{MHz}, \mathrm{C}_{6} \mathrm{D}_{6}\right) \delta 153.6,145.0,139.2,139.1,137.17,137.16,135.1,134.9,134.8$, $129.7,128.8,128.69,128.67,127.6,125.9,123.5,112.6,55.0,33.9,33.6,32.9,32.8$, $32.7,32.5,26.82,26.81,19.02,19.00,17.6,17.5$ (observed complexity due to P-C splitting). ${ }^{31} \mathrm{P}$ NMR $\left(161 \mathrm{MHz}, \mathrm{C}_{6} \mathrm{D}_{6}\right) \delta 38.5 . \mathrm{IR}$ (neat, $\mathrm{cm}^{-1}$ ) 2891, 1593, 1465, 1360, 1264, 1087, 802, 746. HRMS (ESI) calcd for $\mathrm{C}_{29} \mathrm{H}_{39} \mathrm{OP}\left[\mathrm{M}+\mathrm{H}^{+}\right]$: 435.2811. Found: 435.2806 


\section{${ }^{1}$ H-NMR spectrum of $\mathbf{L 7}$}

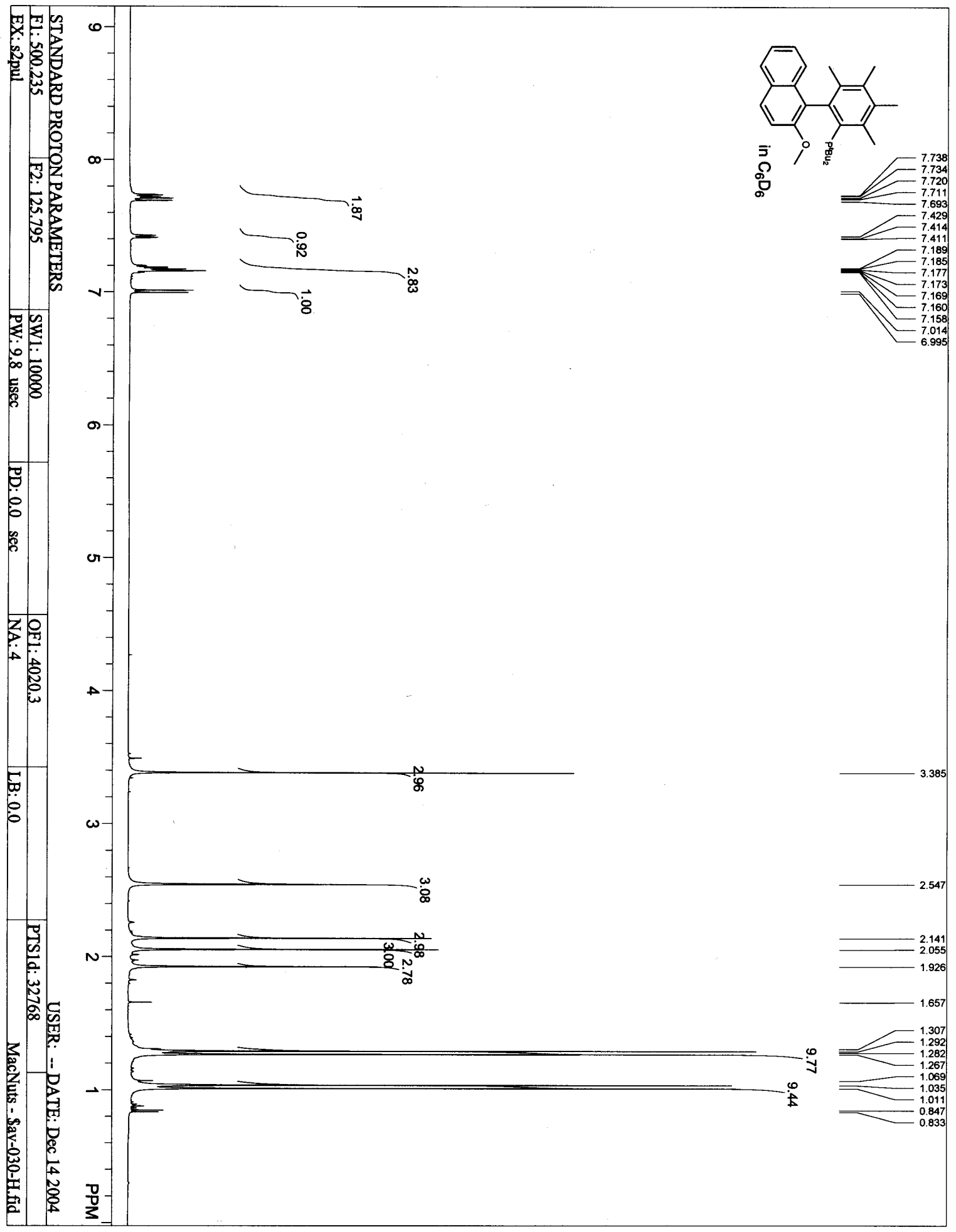




\section{1-(2-Di-tert-butylphosphino-3,4,5,6-tetramethylphenyl)-2-phenylnaphthalene (L8).}

The general procedure for ligand synthesis was followed. Magnesium powder $(0.341 \mathrm{~g}$, $14.20 \mathrm{mmol})$, 1-bromo-2-phenylnaphthalene ${ }^{9}$ (1.75 g, $\left.6.18 \mathrm{mmol}\right)$, 1,2-dibromoethane (43 mg, $20 \mu 1,0.23 \mathrm{mmol}$ ), 1,2-dibromo-3,4,5,6-tetramethylbenzene (1.806 g, 6.18 mmol), copper(I) chloride (0.612 g, $6.18 \mathrm{mmol})$, di-tert-butylchlorophosphine $(1.339 \mathrm{~g}$, $1.48 \mathrm{~mL}, 7.42 \mathrm{mmol})$ and THF $(7 \mathrm{~mL})$ were used. The crude product was purified chromatographically (silica gel). First, a mixture of side products was washed out with hexane. Then the product phosphine was eluted with $20 \%$ ethyl acetate in hexane. The solvent was evaporated and the residue was crystallized from a methyl iso-propyl ketone / ethanol mixture. The crystals were washed with methanol, dried in vacuo to give 0.852 g of the title compound (29\%). Colorless crystals. M.p. $165-167{ }^{\circ} \mathrm{C} .{ }^{1} \mathrm{H}$ NMR (400 $\left.\mathrm{MHz}, \mathrm{C}_{6} \mathrm{D}_{6}\right) \delta 7.72(\mathrm{t}, 2 \mathrm{H}, \mathrm{J}=9.4 \mathrm{~Hz}), 7.66(\mathrm{~d}, 1 \mathrm{H}, \mathrm{J}=8.5 \mathrm{~Hz}), 7.55(\mathrm{~d}, 2 \mathrm{H}, \mathrm{J}=8.3 \mathrm{~Hz})$, $7.38(\mathrm{~d}, 1 \mathrm{H}, \mathrm{J}=8.7 \mathrm{~Hz}), 7.20-7.25(\mathrm{~m}, 1 \mathrm{H}), 7.05-7.13(\mathrm{~m}, 3 \mathrm{H}), 6.93-6.99(\mathrm{~m}, 1 \mathrm{H}), 2.40$ $(\mathrm{s}, 3 \mathrm{H}), 2.14(\mathrm{~s}, 3 \mathrm{H}), 2.06(\mathrm{~s}, 3 \mathrm{H}), 2.05(\mathrm{~s}, 3 \mathrm{H}), 0.88\left(\mathrm{~d}, 9 \mathrm{H}, \mathrm{J}_{\mathrm{HP}}=12.2 \mathrm{~Hz}\right), 0.82(\mathrm{~d}, 9 \mathrm{H}$, $\left.\mathrm{J}_{\mathrm{HP}}=11.9 \mathrm{~Hz}\right) .{ }^{13} \mathrm{C}$ NMR $\left(125 \mathrm{MHz}, \mathrm{C}_{6} \mathrm{D}_{6}\right) \delta 147.3,146.9,143.9,140.3,140.2,140.0$, 137.7, 137.6, 136.66, 136.65, 136.4, 136.3, 135.5, 135.1, 134.8, 134.68, 134.67, 133.5, $131.4,129.7,129.5,128.7,128.0,127.0,125.8,125.6,34.9,34.6,32.71,32.66,32.57$, $32.4,32.2,26.89,26.88,20.25,20.22,17.6,17.5$ (observed complexity due to P-C splitting). ${ }^{31} \mathrm{P}$ NMR (161 MHz, $\left.\mathrm{C}_{6} \mathrm{D}_{6}\right) \delta$ 38.0. IR (neat, $\left.\mathrm{cm}^{-1}\right)$ 2890, 1496, 1465, 1359, 1265, 1169, 821.5, 762, 740, 702. Anal. Calcd for $\mathrm{C}_{34} \mathrm{H}_{41} \mathrm{P}: \mathrm{C}, 84.96 ; \mathrm{H}, 8.60$. Found: $\mathrm{C}$, 84.69; H, 8.56. 


\section{1-(2-Di-tert-butylphosphino-3,4,5,6-tetramethylphenyl)-2-methylnaphthalene (L9).}

The general procedure for ligand synthesis was followed. The crude product was dissolved in $25 \%$ ethyl acetate in hexane, filtered through a plug of silica gel ( $25 \%$ ethyl acetate in hexane). The solvent was evaporated and the residue was crystallized from a methyl iso-propyl ketone / methanol mixture, washed with methanol, dried in vacuo to give $0.655 \mathrm{~g}$ of the title compound $(32 \%)$. Colorless crystals. M.p. $147-148{ }^{\circ} \mathrm{C} .{ }^{1} \mathrm{H}$ $\operatorname{NMR}\left(500 \mathrm{MHz}, \mathrm{C}_{6} \mathrm{D}_{6}\right) \delta 7.71(\mathrm{~d}, 1 \mathrm{H}, \mathrm{J}=8.2 \mathrm{~Hz}), 7.64(\mathrm{~d}, 1 \mathrm{H}, \mathrm{J}=8.2 \mathrm{~Hz}), 7.41(\mathrm{~d}, 1 \mathrm{H}, \mathrm{J}$ $=8.2 \mathrm{~Hz}), 7.29(\mathrm{~d}, 1 \mathrm{H}, \mathrm{J}=8.2 \mathrm{~Hz}), 7.23(\mathrm{t}, 1 \mathrm{H}, \mathrm{J}=7.5 \mathrm{~Hz}), 7.14-7.18(\mathrm{~m}, 1 \mathrm{H}), 2.50(\mathrm{~s}$, $3 \mathrm{H}), 2.20(\mathrm{~s}, 3 \mathrm{H}), 2.16(\mathrm{~s}, 3 \mathrm{H}), 2.09(\mathrm{~s}, 3 \mathrm{H}), 1.83(\mathrm{~s}, 3 \mathrm{H}), 1.17\left(\mathrm{~d}, 9 \mathrm{H}, \mathrm{J}_{\mathrm{HP}}=12.2 \mathrm{~Hz}\right)$ $1.01\left(\mathrm{~d}, 9 \mathrm{H}, \mathrm{J}_{\mathrm{HP}}=12.2 \mathrm{~Hz}\right) .{ }^{13} \mathrm{C}$ NMR $\left(125 \mathrm{MHz}, \mathrm{C}_{6} \mathrm{D}_{6}\right) \delta 147.8,147.4,141.6,141.5$, $139.8,139.7,137.22,137.20,135.9,135.5,135.1,134.85,134.81,134.6,134.5,133.5$, $133.4,132.8,128.9,128.7,128.6,128.5,127.3,125.5,124.9,34.4,34.1,33.6,33.0,32.9$, $32.7,26.77,26.75,22.15,22.14,18.62,18.60,17.6,17.5$ (observed complexity due to PC splitting). ${ }^{31} \mathrm{P}$ NMR $\left(161 \mathrm{MHz}, \mathrm{C}_{6} \mathrm{D}_{6}\right) \delta 36.3 . \mathrm{IR}$ (neat, $\left.\mathrm{cm}^{-1}\right) 2891,1454,1359,1165$, 808, 742. Anal. Calcd for $\mathrm{C}_{29} \mathrm{H}_{39} \mathrm{P}: \mathrm{C}, 83.21 ; \mathrm{H}, 9.39$. Found: C, 82.92; H, 9.52.

\section{1-(2-Di-t-butylphosphino-3,4,5,6-tetramethylphenyl)-2-neopentylnaphthalene (L10).}

\section{Step 1. 1-Bromo-2-neopentylnaphthalene.}

An oven-dried two-neck $250 \mathrm{~mL}$ round-bottom flask was cooled in vacuo, back-filled with argon. One neck was fitted with a rubber septum, another equipped with a reflux 
condenser. The flask was charged with $\mathrm{PdCl}_{2}(\mathrm{dppp})^{10}(442 \mathrm{mg}, 0.75 \mathrm{mmol}), \mathrm{LiBr}(1.305$ g, $15 \mathrm{mmol}$ ) and trifluoromethanesulfonic acid 1-bromonaphthalen-2-yl ester ${ }^{9}$ (5.325 g, $15 \mathrm{mmol})$. The top of the condenser was closed by rubber septum and the apparatus was flushed with argon. Diethyl ether $(132 \mathrm{~mL})$ was added and the stirring was started. The reaction was performed under 1 atmosphere of argon maintained by a balloon. A solution of neopentylmagnesium chloride $(1 \mathrm{M}, 18 \mathrm{~mL}, 18 \mathrm{mmol})$ was added to the reaction mixture at room temperature and the flask was put into a $50{ }^{\circ} \mathrm{C}$ oil bath. The reaction mixture was refluxed for $36 \mathrm{~h}$ and was monitored by TLC for the disappearance of the starting material. Then the mixture was cooled to room temperature and quenched by the dropwise addition of methanol (5 mL, exothermic!). $5 \% \mathrm{HCl}(100 \mathrm{~mL})$ was added and the mixture was transferred into a separatory funnel. The organic layer was separated and the aqueous layer was extracted with diethyl ether. The combined organic layers were dried over $\mathrm{MgSO}_{4}$. The residue after the solvent removal was filtered through a plug of silica gel (hexane), giving, after solvent removal, a yellowish solid (4.047 g). GC analysis: $96 \%$ title compound, $4 \%$ 2-neopentylnaphthalene. Estimated yield of 1-bromo2-neopentylnaphthalene: $3.89 \mathrm{~g}(94 \%)$. The material can be used in the next step without further purification. To obtain the pure product, the solid was stirred with $20 \mathrm{~mL}$ of methanol at room temperature for $1 \mathrm{~h}$. Then the precipitate was isolated by filtration, washed with methanol, dried in vacuo. Obtained $2.646 \mathrm{~g}$ of colorless crystals. M.p. 78 $79{ }^{\circ} \mathrm{C} .{ }^{1} \mathrm{H} \mathrm{NMR}\left(400 \mathrm{MHz}, \mathrm{CDCl}_{3}\right) \delta 8.36(\mathrm{~d}, 1 \mathrm{H}, \mathrm{J}=8.9 \mathrm{~Hz}), 7.78(\mathrm{~d}, 1 \mathrm{H}, \mathrm{J}=7.8 \mathrm{~Hz})$, $7.68(\mathrm{~d}, 1 \mathrm{H}, \mathrm{J}=8.3 \mathrm{~Hz}), 7.53-7.58(\mathrm{~m}, 1 \mathrm{H}), 7.44-7.49(\mathrm{~m}, 1 \mathrm{H}), 7.32(\mathrm{~d}, 1 \mathrm{H}, \mathrm{J}=8.4 \mathrm{~Hz})$ $3.00(\mathrm{~s}, 2 \mathrm{H}), 1.02(\mathrm{~s}, 9 \mathrm{H}) .{ }^{13} \mathrm{C} \mathrm{NMR}\left(100 \mathrm{MHz}, \mathrm{CDCl}_{3}\right) \delta$ 137.8, 133.1, 132.7, 129.9, 
127.91, 127.86, 127.1, 126.4, 125.8, 125.4, 49.2, 33.8, 29.9. IR (neat, $\mathrm{cm}^{-1}$ ) 2960, 1476, 1365, 1265, 821, 740. MS (EI) $278\left[\mathrm{M}^{+},\left\{{ }^{81} \mathrm{Br}\right\}\right], 276\left[\mathrm{M}^{+},\left\{{ }^{79} \mathrm{Br}\right\}\right], 222,220,141$. HRMS (EI) calcd for $\mathrm{C}_{15} \mathrm{H}_{17} \mathrm{Br}: 276.0508\left\{{ }^{79} \mathrm{Br}\right\}$. Found: $276.0511\left\{{ }^{79} \mathrm{Br}\right\}$. 
${ }^{1} \mathrm{H}$ NMR spectrum of 1-bromo-2-neopentylnaphthalene
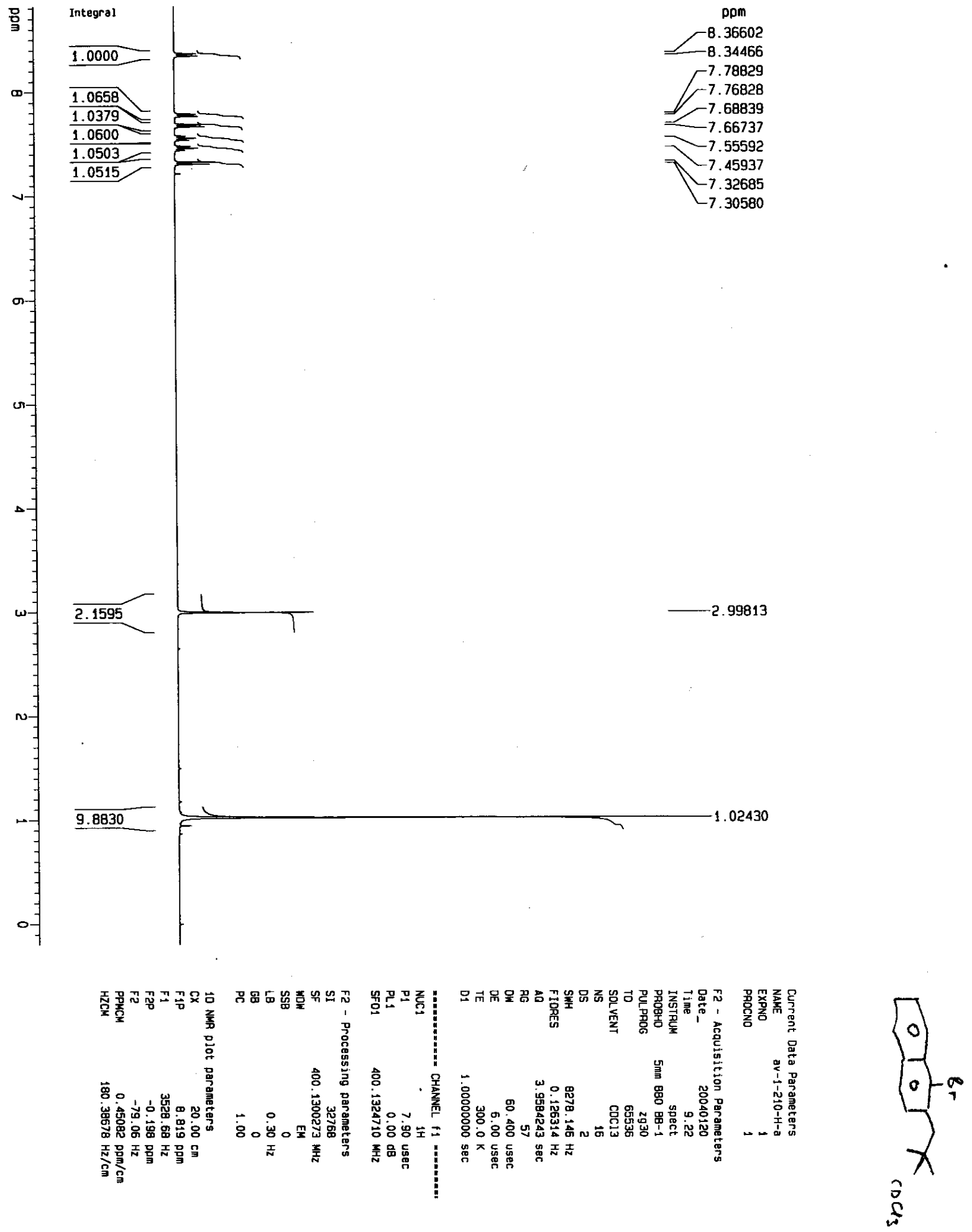


\section{Step 2. 1-(2-Di-tert-butylphosphino-3,4,5,6-tetramethylphenyl)-2- neopentylnaphthalene.}

The procedure used for the synthesis of $\mathbf{L} 6$ was followed. Magnesium powder (2.16 g, 90 mmol), 1-bromo-2-neopentylnaphthalene (10.82 g, 39 mmol), 1,2-dibromo-3,4,5,6tetramethylbenzene (12.556 g, $43 \mathrm{mmol})$, 1,2-dibromoethane (107 mg, $50 \mu 1,0.57$ mmol), copper(I) chloride (3.861 g, $39 \mathrm{mmol})$ and di-tert-butylchlorophosphine ( $8.525 \mathrm{~g}$, $9.45 \mathrm{~mL}, 47 \mathrm{mmol}$ ) were used. The crude product precipitated as yellow solid. It was filtered, washed with water, dried. The filtrate was extracted with $4: 1$ ethyl acetate : diethyl ether ( $2 \times 200 \mathrm{~mL})$. The organic layer was isolated and the aqueous layer was extracted with $4: 1$ ethyl acetate : diethyl ether $(200 \mathrm{~mL})$. The combined organic extracts were dried over $\mathrm{MgSO}_{4}$, the solvent was removed and the residue was united with the previously isolated solid. The product was crystallized from a toluene / ethanol mixture to give white solid, which was washed with methanol. The mother liquor was concentrated and filtered through a plug of silica gel ( $25 \%$ ethyl acetate in hexane). Two additional crops of crystals were collected and the combined product was dried in vacuo. The yield of the title compound was $10.673 \mathrm{~g}(58 \%)$. Colorless crystals. M.p. $184-185{ }^{\circ} \mathrm{C} .{ }^{1} \mathrm{H}$ NMR (400 MHz, $\left.\mathrm{C}_{6} \mathrm{D}_{6}\right) \delta 7.71(\mathrm{~d}, 1 \mathrm{H}, \mathrm{J}=8.2 \mathrm{~Hz}), 7.68(\mathrm{~d}, 1 \mathrm{H}, \mathrm{J}=8.5 \mathrm{~Hz}), 7.60(\mathrm{~d}, 1 \mathrm{H}, \mathrm{J}$ $=8.8 \mathrm{~Hz}), 7.31(\mathrm{~d}, 1 \mathrm{H}, \mathrm{J}=8.5 \mathrm{~Hz}), 7.20-7.25(\mathrm{~m}, 1 \mathrm{H}), 7.07-7.12(\mathrm{~m}, 1 \mathrm{H}), 2.96(\mathrm{~d}, 1 \mathrm{H}, \mathrm{J}$ $=13.5 \mathrm{~Hz}), 2.84(\mathrm{~d}, 1 \mathrm{H}, \mathrm{J}=13.6 \mathrm{~Hz}), 2.51(\mathrm{~s}, 3 \mathrm{H}), 2.10(\mathrm{~s}, 6 \mathrm{H}), 1.92(\mathrm{~s}, 3 \mathrm{H}), 1.40(\mathrm{~d}, 9 \mathrm{H}$, $\left.\mathrm{J}_{\mathrm{HP}}=12.1 \mathrm{~Hz}\right), 0.97(\mathrm{~s}, 9 \mathrm{H}), 0.80\left(\mathrm{~d}, 9 \mathrm{H}, \mathrm{J}_{\mathrm{HP}}=12.1 \mathrm{~Hz}\right) .{ }^{13} \mathrm{C} \mathrm{NMR}\left(100 \mathrm{MHz}, \mathrm{C}_{6} \mathrm{D}_{6}\right) \delta$ $139.9,139.8,137.3,136.50,136.45,135.4,135.2,134.5,132.8,129.6,129.3,126.7$, $125.2,124.9,50.6,50.5,35.2,34.8,34.0,33.6,33.5,33.3,33.2,32.7,32.5,31.5,27.0$, 
21.61, 21.57, 17.7, 17.5 (observed complexity due to P-C splitting). ${ }^{31} \mathrm{P}$ NMR (161 MHz, $\left.\mathrm{C}_{6} \mathrm{D}_{6}\right) \delta$ 39.1. IR (neat, $\left.\mathrm{cm}^{-1}\right)$ 2951, 1465, 1362, 1166, 819, 756, 741. Anal. Calcd for $\mathrm{C}_{33} \mathrm{H}_{47} \mathrm{P}: \mathrm{C}, 83.50 ; \mathrm{H}, 9.98$. Found: C, 83.24; H, 9.94.

\section{1-(2-Di-tert-butylphosphinophenyl)-2-neopentylnaphthalene (L11).}

An oven-dried Schlenk tube was charged with 1-bromo-2-neopentylnaphthalene $(0.723 \mathrm{~g}$, $2.61 \mathrm{mmol})$, 2-chlorophenylboronic acid (0.6 g, $3.834 \mathrm{mmol}), \mathrm{K}_{3} \mathrm{PO}_{4}(1.219 \mathrm{~g}, 5.751$ mmol $), \quad \operatorname{Pd}(\mathrm{OAc})_{2} \quad(8.6 \mathrm{mg}, \quad 0.038 \mathrm{mmol})$, 2-dicyclohexylphosphino-2',6'dimethoxybiphenyl (19 $\mathrm{mg}, 0.046 \mathrm{mmol})$ and toluene $(5 \mathrm{~mL})$. The Schlenk tube was sealed with a Teflon screw cap and placed into a $90{ }^{\circ} \mathrm{C}$ oil bath. The mixture was stirred at $90{ }^{\circ} \mathrm{C}$ for $7 \mathrm{~h}$ and then cooled to room temperature and then quenched by the addition of water. The product was extracted with diethyl ether $(2 \times 25 \mathrm{~mL})$. The combined organic layers were dried over $\mathrm{MgSO}_{4}$. The solvent was removed and the residue was filtered through a plug of silica gel (hexane). A colorless oil was obtained after the removal of solvent, which was analyzed by GC and GC-MS. The coupling product 1-(2chlorophenyl)-2-neopentylnaphthalene was about $90 \%$ pure and was used without further purification. An oven-dried Schlenk tube was charged with magnesium powder (0.081 g, $3.4 \mathrm{mmol})$, 1-(2-chlorophenyl)-2-neopentylnaphthalene (90\% pure) and THF (3 $\mathrm{mL}$ ). The Schlenk tube was put into a $60{ }^{\circ} \mathrm{C}$ oil bath and 1,2-dibromoethane ( $22 \mathrm{mg}, 10$ $\mu 1,0.12 \mathrm{mmol}$ ) was added dropwise via syringe over $5 \mathrm{~min}$. The mixture was stirred at 60 ${ }^{\circ} \mathrm{C}$ for $20 \mathrm{~min}$ and then 1,2-dibromoethane (43 mg, $20 \mu \mathrm{l}, 0.23 \mathrm{mmol}$ ) was added. The tube was sealed with a Teflon screw cap, then the mixture was stirred at $75^{\circ} \mathrm{C}$ for $17 \mathrm{~h}$. 
The mixture was then cooled to room temperature. Copper(I) chloride $(0.258 \mathrm{~g}, 2.61$ mmol) was weighed in the glovebox and removed from the glovebox right before its addition into the above reaction mixture under a flow of argon, followed by the addition of di-tert-butylchlorophosphine $(0.471 \mathrm{~g}, 0.52 \mathrm{~mL}, 2.61 \mathrm{mmol})$. The Schlenk tube was sealed with a Teflon screw cap and put into a $75{ }^{\circ} \mathrm{C}$ oil bath. The reaction mixture was stirred at $75{ }^{\circ} \mathrm{C}$ for $30 \mathrm{~h}$. The Schlenk tube was taken out of the $75^{\circ} \mathrm{C}$ oil bath and allowed to cool to room temperature. The reaction mixture was quenched with $30 \%$ aqueous $\mathrm{NH}_{4} \mathrm{OH}$ solution $(25 \mathrm{~mL})$. The resulting suspension was extracted with $4: 1$ ethyl acetate : diethyl ether $(50 \mathrm{~mL})$. The organic layer was separated and washed with 30 $\%$ aqueous $\mathrm{NH}_{4} \mathrm{OH}(3 \times 25 \mathrm{~mL})$ and the phosphine products were extracted into the aqueous layer by $10 \% \mathrm{HCl}(2 \times 50 \mathrm{~mL})$. The combined organic layers were basified by the addition of $10 \% \mathrm{NaOH}$, extracted with $4: 1$ ethyl acetate : diethyl ether $(2 \times 25 \mathrm{~mL})$. The crude product was isolated by solvent removal, filtered through a plug of silica gel (hexane), crystallized from methanol by passing the flow of $\mathrm{N}_{2}$ over the solution, washed with methanol, dried in vacuo to give $0.339 \mathrm{~g}$ of the title compound (31\%). Colorless crystals. M.p. $109-110{ }^{\circ} \mathrm{C} .{ }^{1} \mathrm{H}$ NMR $\left(400 \mathrm{MHz}, \mathrm{C}_{6} \mathrm{D}_{6}\right) \delta$ 7.87-7.92 (m, 1H), $7.70(\mathrm{~d}, 1 \mathrm{H}$, $\mathrm{J}=8.0 \mathrm{~Hz}), 7.67(\mathrm{~d}, 1 \mathrm{H}, \mathrm{J}=8.5 \mathrm{~Hz}), 7.50(\mathrm{~d}, 1 \mathrm{H}, \mathrm{J}=8.5 \mathrm{~Hz}), 7.47(\mathrm{~d}, 1 \mathrm{H}, \mathrm{J}=8.0 \mathrm{~Hz})$ 7.36-7.42 (m, 1H), 7.17-7.25 (m, 3H), 7.11-7.16 (m, 1H), $2.98(\mathrm{~d}, 1 \mathrm{H}, \mathrm{J}=12.9 \mathrm{~Hz}), 2.70$ $(\mathrm{d}, 1 \mathrm{H}, \mathrm{J}=13.2 \mathrm{~Hz}), 1.29\left(\mathrm{~d}, 9 \mathrm{H}, \mathrm{J}_{\mathrm{HP}}=11.2 \mathrm{~Hz}\right), 0.88(\mathrm{~s}, 9 \mathrm{H}), 0.81\left(\mathrm{~d}, 1 \mathrm{H}, \mathrm{J}_{\mathrm{HP}}=11.2\right.$ $\mathrm{Hz}) .{ }^{13} \mathrm{C}$ NMR $\left(125 \mathrm{MHz}, \mathrm{C}_{6} \mathrm{D}_{6}\right) \delta 148.5,148.3,139.9,139.8,139.2,138.9,136.58$, $136.56,136.00,135.98,135.02,134.97,134.6,133.2,129.8,128.7,127.2,126.6,125.5$ $125.1,49.30,49.26,33.8,33.1,32.9,32.8,32.7,32.4,32.3,31.1,30.9$ (observed 
complexity due to P-C splitting). ${ }^{31} \mathrm{P}$ NMR $\left(161 \mathrm{MHz}, \mathrm{C}_{6} \mathrm{D}_{6}\right) \delta 23.7$. IR (neat, $\left.\mathrm{cm}^{-1}\right) 3052$, 2951, 1475, 1385, 1363, 1173, 822, 756. Anal. Calcd for $\mathrm{C}_{29} \mathrm{H}_{39} \mathrm{P}: \mathrm{C}, 83.21 ; \mathrm{H}, 9.39$. Found: C, 83.05; H, 9.57.

\section{Coupling of 5-bromo-m-xylene with 2-butanol. Ligand evaluation (Table 1).}

Ten oven-dried Schlenk tubes were cooled in vacuo and then back-filled with argon. Each tube was charged with $\mathrm{Pd}(\mathrm{OAc})_{2}(2.2 \mathrm{mg}, 0.01 \mathrm{mmol})$, appropriate ligand $\mathbf{L 1}-\mathbf{L 1 0}$ (1.2 mmol) and $\mathrm{Cs}_{2} \mathrm{CO}_{3}(245 \mathrm{mg}, 0.75 \mathrm{mmol})$. The Schlenk tubes were fitted with rubber septa, evacuated and back-filled with argon. 5-Bromo-m-xylene (1a) (93 mg, $0.5 \mathrm{mmol})$, 2-butanol (74 mg, $1 \mathrm{mmol})$ and dodecane $(85 \mathrm{mg}, 0.5 \mathrm{mmol})$ were added into each tube through the septum via syringe, followed by dry toluene $(1 \mathrm{~mL})$. Then the septa were replaced with Teflon screw caps under argon, the tubes were sealed and placed in an oil bath $\left(90{ }^{\circ} \mathrm{C}\right)$ for $24 \mathrm{~h}$. After this time the reaction mixtures were cooled to room temperature, filtered through a layer of Celite with the aid of ethyl acetate and analyzed by GC. The corrected GC yields of the starting 1a and the products 1-sec-butoxy-3,5dimethylbenzene (2a), $m$-xylene (3), di-(3,5-dimethylphenyl)ether ${ }^{11}$ (4) and 3,3',5,5'tetramethylbiphenyl $1^{12}(\mathbf{5})$ were measured. The results are reported in table 1.

\section{General Procedure for the Intermolecular Coupling of Alcohols with Aryl Halides.}

An oven-dried Schlenk tube was cooled in vacuo, back-filled with argon and charged with $\mathrm{Pd}(\mathrm{OAc})_{2}$, ligand and $\mathrm{Cs}_{2} \mathrm{CO}_{3}$. The Schlenk tube was fitted with rubber septum, evacuated, and back-filled with argon. The aryl halide and alcohol were added through 
the septum via syringe, followed by the solvent. The septum was replaced with a Teflon screw cap under a counterflow of argon, the tube was sealed and was placed in an oil bath. The reaction was conducted under the conditions indicated below. After the reaction mixture was allowed to cool to room temperature, it was filtered through a layer of Celite with the aid of ethyl acetate. In the cases where toluene was used as the solvent, the filtrate was concentrated in vacuo and the crude product was purified chromatographically (silica gel). In the cases where $\mathrm{Bu}_{3} \mathrm{~N}$ was used as the solvent, the filtrate was extracted with $10 \% \mathrm{HCl}$. The organic layer was isolated and the aqueous layer was back extracted with diethyl ether. The combined organic extracts were dried over $\mathrm{MgSO}_{4}$ and the crude product was purified chromatographically (silica gel). The yields of the coupling products are indicated below.

\section{1-sec-butoxy-3,5-dimethylbenzene (2a)}

The general procedure was followed using $\mathrm{Pd}(\mathrm{OAc})_{2}(4.5 \mathrm{mg}, 0.02 \mathrm{mmol}), \mathbf{L 1 0}$ (11.4 mg, $0.024 \mathrm{mmol}), \mathrm{Cs}_{2} \mathrm{CO}_{3}$ (489 mg, $\left.1.5 \mathrm{mmol}\right), 5$-bromo- $m$-xylene (185 mg, $\left.1 \mathrm{mmol}\right), 2-$ butanol (148 mg, $2 \mathrm{mmol})$ with $\mathrm{Bu}_{3} \mathrm{~N}(1 \mathrm{~mL})$ as solvent for $24 \mathrm{~h}$ at $90{ }^{\circ} \mathrm{C}$. The filtrate was extracted with $10 \% \mathrm{HCl}(2 \times 20 \mathrm{~mL})$. The combined organic extracts were concentrated to exactly $5 \mathrm{~mL}, 0.5 \mathrm{~mL}$ of this solution was taken, mixed with $0.1 \mathrm{M}$ solution of dodecane in ethyl acetate $(1 \mathrm{~mL})$ and the resulting solution was analyzed by GC. GC yelds: 2a (76\%), 3 (5\%), 4 (4\%), 5 (6\%). Chromatographic purification (hexane, followed by $5 \%$ ethyl acetate in hexane) provided $\mathbf{2 a}$ (colorless liquid, $132 \mathrm{mg}, 74 \%$ ).

${ }^{1} \mathrm{H}$ NMR $\left(400 \mathrm{MHz}, \mathrm{CDCl}_{3}\right) \delta 6.57(\mathrm{~s}, 1 \mathrm{H}), 6.52(\mathrm{~s}, 2 \mathrm{H}), 4.26($ sextet, $1 \mathrm{H}, \mathrm{J}=6.1 \mathrm{~Hz})$, 
$2.28(\mathrm{~s}, 6 \mathrm{H}), 1.67-1.78(\mathrm{~m}, 1 \mathrm{H}), 1.56-1.65(\mathrm{~m}, 1 \mathrm{H}), 1.27(\mathrm{~d}, 3 \mathrm{H}, \mathrm{J}=6.0 \mathrm{~Hz}), 0.97(\mathrm{t}, 3 \mathrm{H}$, $\mathrm{J}=7.5 \mathrm{~Hz}) .{ }^{13} \mathrm{C} \mathrm{NMR}\left(100 \mathrm{MHz}, \mathrm{CDCl}_{3}\right) \delta 158.2,139.1,122.2,113.6,74.7,29.3,21.4$, 19.3, 9.9. IR (neat, $\left.\mathrm{cm}^{-1}\right)$ 2972, 2922, 1594, 1465, 1321, 1294, 1180, 1153, 1125, 1052 , 828, 690. Anal. Calcd for $\mathrm{C}_{12} \mathrm{H}_{18} \mathrm{O}: \mathrm{C}, 80.85 ; \mathrm{H}, 10.18$. Found: $\mathrm{C}, 81.02 ; \mathrm{H}, 10.27$.

\section{1-Cyclopentyloxy-3,5-dimethylbenzene (2b)}

The general procedure was followed using $\mathrm{Pd}(\mathrm{OAc})_{2}$ (4.5 mg, $\left.0.02 \mathrm{mmol}\right), \mathbf{L 1 0}$ (11.4 mg, $0.024 \mathrm{mmol}), \mathrm{Cs}_{2} \mathrm{CO}_{3}(489 \mathrm{mg}, 1.5 \mathrm{mmol}), 5$-bromo- $m$-xylene $(185 \mathrm{mg}, 1 \mathrm{mmol})$ and cyclopentanol $(172 \mathrm{mg}, 2 \mathrm{mmol})$ with $\mathrm{Bu}_{3} \mathrm{~N}(2 \mathrm{~mL})$ as solvent for $24 \mathrm{~h}$ at $90{ }^{\circ} \mathrm{C}$. The filtrate was extracted with $10 \% \mathrm{HCl}(2 \times 35 \mathrm{~mL})$. Chromatographic purification (hexane, followed by $5 \%$ ethyl acetate in hexane) provided $\mathbf{2 b}$ (colorless liquid, $144 \mathrm{mg}, 76 \%$ ).

${ }^{1} \mathrm{H}$ NMR (400 MHz, $\left.\mathrm{CDCl}_{3}\right) \delta 6.56(\mathrm{~s}, 1 \mathrm{H}), 6.51(\mathrm{~s}, 2 \mathrm{H}), 4.70-4.75(\mathrm{~m}, 1 \mathrm{H}), 2.27(\mathrm{~s}, 6 \mathrm{H})$, 1.73-1.93 (m, 6H), 1.56-1.64 (m, 2H). ${ }^{13} \mathrm{C}$ NMR (100 MHz, $\left.\mathrm{CDCl}_{3}\right) \delta$ 158.1, 139.0, 122.0, 113.2, 78.8, 32.9, 24.0, 21.5. IR (neat, $\left.\mathrm{cm}^{-1}\right)$ 2961, 1594, 1471, 1325, 1294, 1155 , 1053, 829, 689. Anal. Calcd for $\mathrm{C}_{13} \mathrm{H}_{18} \mathrm{O}: \mathrm{C}, 82.06 ; \mathrm{H}, 9.53$. Found: C, 82.09; H, 9.66.

\section{1,3-Dimethyl-5-(1-methyl-2-phenylethoxy)-benzene (2c)}

The general procedure was followed using $\mathrm{Pd}(\mathrm{OAc})_{2}(6.7 \mathrm{mg}, 0.03 \mathrm{mmol}), \mathbf{L 1 0}(17.1 \mathrm{mg}$, $0.036 \mathrm{mmol}), \mathrm{Cs}_{2} \mathrm{CO}_{3}$ (489 mg, $\left.1.5 \mathrm{mmol}\right), 5$-bromo-m-xylene (185 mg, $\left.1 \mathrm{mmol}\right), 1$ phenylpropan-2-ol (272 mg, $2 \mathrm{mmol})$ with $\mathrm{Bu}_{3} \mathrm{~N}(4 \mathrm{~mL})$ as solvent for $24 \mathrm{~h}$ at $90{ }^{\circ} \mathrm{C}$. The filtrate was extracted with $10 \% \mathrm{HCl}(2 \times 50 \mathrm{~mL})$. Chromatographic purification (hexane) 
provided 2c (colorless liquid, $164 \mathrm{mg}, 68 \%) .{ }^{1} \mathrm{H}$ NMR $\left(400 \mathrm{MHz}, \mathrm{CDCl}_{3}\right) \delta$ 7.19-7.33 $(\mathrm{m}, 5 \mathrm{H}), 6.58(\mathrm{~s}, 1 \mathrm{H}), 6.52(\mathrm{~s}, 2 \mathrm{H}), 4.55($ sextet, $1 \mathrm{H}, \mathrm{J}=6.0 \mathrm{~Hz}), 3.09(\mathrm{dd}, 1 \mathrm{H}, \mathrm{J}=13.6$, $6.0 \mathrm{~Hz}), 2.80(\mathrm{dd}, 1 \mathrm{H}, \mathrm{J}=13.6,6.7 \mathrm{~Hz}), 2.27(\mathrm{~s}, 6 \mathrm{H}), 1.28(\mathrm{~d}, 3 \mathrm{H}, \mathrm{J}=6.0 \mathrm{~Hz}) .{ }^{13} \mathrm{C} \mathrm{NMR}$ $\left(100 \mathrm{MHz}, \mathrm{CDCl}_{3}\right) \delta 157.8,139.1,138.3,129.5,128.3,126.3,122.4,113.7,74.3,42.7$, 21.4, 19.4. IR (neat, $\mathrm{cm}^{-1}$ ) 2919, 1593, 1454, 1377, 1295, 1155, 1077, 829, 745, 700. Anal. Calcd for $\mathrm{C}_{17} \mathrm{H}_{20} \mathrm{O}$ : C, 84.96; H, 8.39. Found: C, 84.70; H, 8.35.

\section{1,3-Dimethyl-5-(1,2,2-trimethylpropoxy)-benzene (2d)}

The general procedure was followed using $\mathrm{Pd}(\mathrm{OAc})_{2}(4.5 \mathrm{mg}, 0.02 \mathrm{mmol}), \mathbf{L 1 0}$ (11.4 mg, $0.024 \mathrm{mmol}), \mathrm{Cs}_{2} \mathrm{CO}_{3}(489 \mathrm{mg}, 1.5 \mathrm{mmol}), 5$-bromo-m-xylene (185 mg, $\left.1 \mathrm{mmol}\right), 3,3-$ dimethylbutan-2-ol (204 mg, $2 \mathrm{mmol})$ with $\mathrm{Bu}_{3} \mathrm{~N}(1 \mathrm{~mL})$ as solvent for $24 \mathrm{~h}$ at $90{ }^{\circ} \mathrm{C}$. The filtrate was extracted with $10 \% \mathrm{HCl}(2 \times 25 \mathrm{~mL})$. Chromatographic purification (hexane) provided a colorless liquid (124 $\mathrm{mg}$ ), which was a mixture of $\mathbf{2 d}$ and a small amount of $\mathbf{5}$ that could not be fully separated. The amount of $\mathbf{2 d}$ in the mixture was estimated using GC and ${ }^{1} \mathrm{H}-\mathrm{NMR}: 117 \mathrm{mg}(57 \%)$. Further chromatographic purification (2\% methylene chloride in hexane) of the small amount of the mixture $\left(50 \mathrm{mg}\right.$ ) provided pure $2 \mathbf{d} .{ }^{1} \mathrm{H}$ $\operatorname{NMR}\left(400 \mathrm{MHz}, \mathrm{CDCl}_{3}\right) \delta 6.56(\mathrm{~s}, 1 \mathrm{H}), 6.53(\mathrm{~s}, 2 \mathrm{H}), 3.99(\mathrm{q}, 1 \mathrm{H}, \mathrm{J}=6.3 \mathrm{~Hz}), 2.28(\mathrm{~s}$, $6 \mathrm{H}), 1.18(\mathrm{~d}, 3 \mathrm{H}, \mathrm{J}=6.3 \mathrm{~Hz}), 0.98(\mathrm{~s}, 9 \mathrm{H}) .{ }^{13} \mathrm{C} \mathrm{NMR}\left(100 \mathrm{MHz}, \mathrm{CDCl}_{3}\right) \delta$ 158.9, 139.1, 122.0, 113.5, 80.8, 35.0, 25.9, 21.4, 14.2. IR (neat, $\left.\mathrm{cm}^{-1}\right)$ 2959, 1595, 1470, 1376, 1321, $1295,1155,1082,954,829,689$. Anal. Calcd for $\mathrm{C}_{14} \mathrm{H}_{22} \mathrm{O}: \mathrm{C}, 81.50 ; \mathrm{H}, 10.75$. Found: $\mathrm{C}$, $81.61 ; \mathrm{H}, 10.85$. 


\section{1-(1,3-Dimethylbut-2-enyloxy)-3,5-dimethylbenzene (2e)}

The general procedure was followed using $\mathrm{Pd}(\mathrm{OAc})_{2}(4.5 \mathrm{mg}, 0.02 \mathrm{mmol}), \mathbf{L 1 0}$ (11.4 mg, $0.024 \mathrm{mmol}), \mathrm{Cs}_{2} \mathrm{CO}_{3}(489 \mathrm{mg}, 1.5 \mathrm{mmol}), 5$-bromo-m-xylene (185 mg, $\left.1 \mathrm{mmol}\right), 4-$ methylpent-3-en-2-ol (200 mg, $2 \mathrm{mmol})$ with $\mathrm{Bu}_{3} \mathrm{~N}(2 \mathrm{~mL})$ as solvent for $18 \mathrm{~h}$ at $50{ }^{\circ} \mathrm{C}$. The filtrate was extracted with $10 \% \mathrm{HCl}(2 \times 35 \mathrm{~mL})$. Chromatographic purification (1 $\%$ ethyl acetate in hexane) provided 2e (colorless liquid, $165 \mathrm{mg}, 81 \%) .{ }^{1} \mathrm{H}$ NMR (400 $\left.\mathrm{MHz}, \mathrm{CDCl}_{3}\right) \delta 6.56(\mathrm{~s}, 1 \mathrm{H}), 6.50(\mathrm{~s}, 2 \mathrm{H}), 5.20-5.24(\mathrm{~m}, 1 \mathrm{H}), 4.93-5.01(\mathrm{~m}, 1 \mathrm{H}), 2.26(\mathrm{~m}$ $6 \mathrm{H}), 1.73(\mathrm{~d}, 3 \mathrm{H}, \mathrm{J}=1.3 \mathrm{~Hz}), 1.72(\mathrm{~d}, 3 \mathrm{H}, \mathrm{J}=1.3 \mathrm{~Hz}), 1.35(\mathrm{~d}, 3 \mathrm{H}, \mathrm{J}=6.2 \mathrm{~Hz}) .{ }^{13} \mathrm{C}$ NMR $\left(100 \mathrm{MHz}, \mathrm{CDCl}_{3}\right) \delta 158.0,138.9,134.0,127.1,122.1,113.5,70.7,25.6,21.4,21.3$, 18.2. IR (neat, $\mathrm{cm}^{-1}$ ) 2975, 1595, 1448, 1292, 1155, 1067, 827, 688. Anal. Calcd for $\mathrm{C}_{14} \mathrm{H}_{20} \mathrm{O}: \mathrm{C}, 82.30 ; \mathrm{H}, 9.87$. Found: C, 81.95; H, 9.84.

\section{(R)-1,3-Dimethyl-5-(1-phenylethoxy)-benzene (2f)}

The general procedure was followed using $\mathrm{Pd}(\mathrm{OAc})_{2}(4.5 \mathrm{mg}, 0.02 \mathrm{mmol}), \mathbf{L 1 0}(11.4 \mathrm{mg}$, $0.024 \mathrm{mmol}), \mathrm{Cs}_{2} \mathrm{CO}_{3}$ (489 mg, $\left.1.5 \mathrm{mmol}\right), 5$-bromo-m-xylene (185 mg, $\left.1 \mathrm{mmol}\right),(R)-1$ phenylethanol (98\% ee) (244 mg, $2 \mathrm{mmol})$ with $\mathrm{Bu}_{3} \mathrm{~N}(4 \mathrm{~mL})$ as solvent for $24 \mathrm{~h}$ at 90 ${ }^{\circ} \mathrm{C}$. The filtrate was extracted with $10 \% \mathrm{HCl}(2 \times 50 \mathrm{~mL})$. Chromatographic purification (hexane, followed by $2 \%$ ethyl acetate in hexane) provided $(R)-\mathbf{2 f}$ (colorless liquid, 158 mg, $70 \%) \cdot[\alpha]^{20}{ }_{D}=12.17^{\circ}\left(\mathrm{c}=1, \mathrm{CH}_{2} \mathrm{Cl}_{2}\right)$. HPLC: Chiralcel OJ Column, $\mathrm{t}[$ major $]=9.5$ $\min , \mathrm{t}[\mathrm{minor}]=11.0 \mathrm{~min}(10 \%$ isopropanol in hexane, $1 \mathrm{~mL} / \mathrm{min}), 98 \%$ ee. ${ }^{1} \mathrm{H}$ NMR 
$\left(400 \mathrm{MHz}, \mathrm{CDCl}_{3}\right) \delta$ 7.30-7.39 (m, 4H), 7.22-7.27 (m, 1H), $6.53(\mathrm{~s}, 1 \mathrm{H}), 6.50(\mathrm{~s}, 2 \mathrm{H})$,

$5.29(\mathrm{q}, 1 \mathrm{H}, \mathrm{J}=6.5 \mathrm{~Hz}), 2.22(\mathrm{~s}, 6 \mathrm{H}), 1.60(\mathrm{~d}, 3 \mathrm{H}, \mathrm{J}=6.4 \mathrm{~Hz}) .{ }^{13} \mathrm{C}$ NMR $(100 \mathrm{MHz}$ $\left.\mathrm{CDCl}_{3}\right) \delta 158.0,143.4,139.0,128.5,127.3,125.5,122.4,113.6,75.5,24.4,21.4 . \mathrm{IR}$ $\left(\right.$ neat, $\left.\mathrm{cm}^{-1}\right)$ 2978, 1595, 1451, 1321, 1293, 1154, 1071, 828, 760, 700. Anal. Calcd for $\mathrm{C}_{16} \mathrm{H}_{18} \mathrm{O}: \mathrm{C}, 84.91 ; \mathrm{H}, 8.02$. Found: $\mathrm{C}, 84.76 ; \mathrm{H}, 8.07$.

\section{1-sec-butoxy-4-butylbenzene (2g)}

A. The general procedure was followed using $\mathrm{Pd}(\mathrm{OAc})_{2}(4.5 \mathrm{mg}, 0.02 \mathrm{mmol}), \mathbf{L 1 0}$ (11.4 mg, $0.024 \mathrm{mmol}$ ), $\mathrm{Cs}_{2} \mathrm{CO}_{3}$ (489 mg, $1.5 \mathrm{mmol}$ ), 1-bromo-4-butylbenzene (214 mg, 1 mmol), 2-butanol (148 mg, $2 \mathrm{mmol})$ with $\mathrm{Bu}_{3} \mathrm{~N}(1 \mathrm{~mL})$ as solvent for $24 \mathrm{~h}$ at $90{ }^{\circ} \mathrm{C}$. The filtrate was extracted with $10 \% \mathrm{HCl}(2 \times 20 \mathrm{~mL})$. Chromatographic purification (hexane, followed by $5 \%$ ethyl acetate in hexane) provided $\mathbf{2 g}$ (colorless liquid, 149 mg, $72 \%)$.

B. The general procedure was followed using $\mathrm{Pd}(\mathrm{OAc})_{2}(4.5 \mathrm{mg}, 0.02 \mathrm{mmol}), \mathbf{L 1 0}$ (11.4 $\mathrm{mg}, 0.024 \mathrm{mmol}), \mathrm{Cs}_{2} \mathrm{CO}_{3}$ (489 mg, $1.5 \mathrm{mmol}$ ), 1-chloro-4-butylbenzene (169 mg, 1 mmol), 2-butanol (148 mg, $2 \mathrm{mmol})$ with $\mathrm{Bu}_{3} \mathrm{~N}(1 \mathrm{~mL})$ as solvent for $24 \mathrm{~h}$ at $100{ }^{\circ} \mathrm{C}$. The filtrate was extracted with $10 \% \mathrm{HCl}(2 \times 20 \mathrm{~mL})$. Chromatographic purification (hexane, followed by $5 \%$ ethyl acetate in hexane) provided $\mathbf{2 g}$ (colorless liquid, 144 mg, $70 \%) .{ }^{1} \mathrm{H}$ NMR (400 MHz, $\left.\mathrm{CDCl}_{3}\right) \delta 7.07$ (d, 2H, J = $\left.8.6 \mathrm{~Hz}\right), 6.80(\mathrm{~d}, 2 \mathrm{H}, \mathrm{J}=$ $8.7 \mathrm{~Hz}), 4.24($ sextet, $1 \mathrm{H}, \mathrm{J}=6.3 \mathrm{~Hz}), 2.54(\mathrm{t}, 2 \mathrm{H}, \mathrm{J}=7.7 \mathrm{~Hz}), 1.68-1.79(\mathrm{~m}, 1 \mathrm{H})$, 1.52-1.65 (m, 3H), $1.34($ sextet, $2 \mathrm{H}, \mathrm{J}=7.5 \mathrm{~Hz}), 1.28(\mathrm{~d}, 3 \mathrm{H}, \mathrm{J}=6.1 \mathrm{~Hz}), 0.97(\mathrm{t}, 3 \mathrm{H}$, 
$\mathrm{J}=7.5 \mathrm{~Hz}), 0.92(\mathrm{t}, 3 \mathrm{H}, \mathrm{J}=7.3 \mathrm{~Hz}) .{ }^{13} \mathrm{C} \mathrm{NMR}\left(100 \mathrm{MHz}, \mathrm{CDCl}_{3}\right) \delta 156.2,134.8$, 129.2, 115.7, 75.0, 34.7, 33.9, 29.2, 22.3, 19.3, 14.0, 9.8. IR (neat, $\left.\mathrm{cm}^{-1}\right) 2930,1612$, $1509,1465,1377,1241,1128,989,827$. Anal. Calcd for $\mathrm{C}_{14} \mathrm{H}_{22} \mathrm{O}: \mathrm{C}, 81.50 ; \mathrm{H}, 10.75$. Found: C, 81.36; H, 10.81 .

\section{1-Butyl-4-(1,3-dimethylbut-2-enyloxy)-benzene (2h)}

A. The general procedure was followed using $\mathrm{Pd}(\mathrm{OAc})_{2}(4.5 \mathrm{mg}, 0.02 \mathrm{mmol}), \mathbf{L 1 0}(11.4$ mg, $0.024 \mathrm{mmol}$ ), $\mathrm{Cs}_{2} \mathrm{CO}_{3}$ (489 mg, $1.5 \mathrm{mmol}$ ), 1-bromo-4-butylbenzene (214 mg, 1 mmol), 4-methylpent-3-en-2-ol (200 mg, 2 mmol) with $\mathrm{Bu}_{3} \mathrm{~N}(2 \mathrm{~mL})$ as solvent for 18 h at $50{ }^{\circ} \mathrm{C}$. The filtrate was extracted with $10 \% \mathrm{HCl}(2 \times 35 \mathrm{~mL})$. Chromatographic purification (1\% ethyl acetate in hexane) provided $\mathbf{2 h}$ (colorless liquid, $176 \mathrm{mg}, 76$ $\%)$.

B. The general procedure was followed using $\mathrm{Pd}(\mathrm{OAc})_{2}(11.2 \mathrm{mg}, 0.05 \mathrm{mmol}), \mathbf{L 1 0}$ (28.4 mg, $0.06 \mathrm{mmol}), \mathrm{Cs}_{2} \mathrm{CO}_{3}(489 \mathrm{mg}, 1.5 \mathrm{mmol}$ ), 1-chloro-4-butylbenzene (169 $\mathrm{mg}, 1 \mathrm{mmol})$, 4-methylpent-3-en-2-ol (200 mg, $2 \mathrm{mmol})$ with $\mathrm{Bu}_{3} \mathrm{~N}(2 \mathrm{~mL})$ as solvent for $18 \mathrm{~h}$ at $50{ }^{\circ} \mathrm{C}$. The filtrate was extracted with $10 \% \mathrm{HCl}(2 \times 35 \mathrm{~mL})$. Chromatographic purification (1\% ethyl acetate in hexane) provided $\mathbf{2 h}$ (colorless liquid, $183 \mathrm{mg}, 79 \%) .{ }^{1} \mathrm{H}$ NMR (400 MHz, $\left.\mathrm{CDCl}_{3}\right) \delta 7.05(\mathrm{~d}, 2 \mathrm{H}, \mathrm{J}=8.7 \mathrm{~Hz}), 6.78$ $(\mathrm{d}, 2 \mathrm{H}, \mathrm{J}=8.6 \mathrm{~Hz}), 5.20-5.25(\mathrm{~m}, 1 \mathrm{H}), 4.91-4.99(\mathrm{~m}, 1 \mathrm{H}), 2.53(\mathrm{t}, 2 \mathrm{H}, \mathrm{J}=7.7 \mathrm{~Hz})$, $1.72(\mathrm{~s}, 3 \mathrm{H}), 1.71(\mathrm{~s}, 3 \mathrm{H}), 1.51-1.60(\mathrm{~m}, 2 \mathrm{H}), 1.36(\mathrm{~d}, 3 \mathrm{H}, \mathrm{J}=6.4 \mathrm{~Hz}), 1.29-1.40(\mathrm{~m}$, 2H), $0.91(\mathrm{t}, 3 \mathrm{H}, \mathrm{J}=7.4 \mathrm{~Hz}) .{ }^{13} \mathrm{C} \mathrm{NMR}\left(100 \mathrm{MHz}, \mathrm{CDCl}_{3}\right) \delta 156.5,135.2,134.5$, $129.5,127.7,116.1,71.6,35.2,34.3,26.1,22.8,21.8,18.7,14.4$. IR (neat, $\left.\mathrm{cm}^{-1}\right) 2929$, 
$2858,1612,1509,1447,1376,1239,1065,950,828$. Anal. Calcd for $\mathrm{C}_{16} \mathrm{H}_{24} \mathrm{O}: \mathrm{C}$,

82.70; H, 10.41. Found: C, 82.64; H, 10.65 .

\section{1-sec-butoxy-3-trifluoromethylbenzene (2i)}

The general procedure was followed using $\mathrm{Pd}(\mathrm{OAc})_{2}(4.5 \mathrm{mg}, 0.02 \mathrm{mmol}), \mathbf{L 1 0}$ (11.4 mg, $0.024 \mathrm{mmol}), \mathrm{Cs}_{2} \mathrm{CO}_{3}$ (489 mg, $1.5 \mathrm{mmol}$ ), 1-chloro-3-trifluoromethylbenzene (181 mg, $1 \mathrm{mmol})$, 2-butanol $(148 \mathrm{mg}, 2 \mathrm{mmol})$ with $\mathrm{Bu}_{3} \mathrm{~N}(1 \mathrm{~mL})$ as solvent for $24 \mathrm{~h}$ at $90{ }^{\circ} \mathrm{C}$. The filtrate was extracted with $10 \% \mathrm{HCl}(2 \times 20 \mathrm{~mL})$. Chromatographic purification (hexane) provided 2i (colorless liquid, $175 \mathrm{mg}, 80 \%) .{ }^{1} \mathrm{H}$ NMR (400 MHz, $\mathrm{CDCl}_{3}$ ) $\delta 7.37$ (t, 1H, J $=8.1 \mathrm{~Hz}), 7.17(\mathrm{~d}, 1 \mathrm{H}, \mathrm{J}=7.8 \mathrm{~Hz}), 7.11(\mathrm{~s}, 1 \mathrm{H}), 7.04(\mathrm{~d}, 1 \mathrm{H}), 4.34($ sextet, $1 \mathrm{H}, \mathrm{J}=6.0$ Hz), 1.70-1.82 (m, 1H), 1.59-1.70 (m, 1H), $1.31(\mathrm{~d}, 3 \mathrm{H}, \mathrm{J}=6.1 \mathrm{~Hz}), 0.99(\mathrm{t}, 3 \mathrm{H}, \mathrm{J}=7.5$ $\mathrm{Hz}) .{ }^{13} \mathrm{C}$ NMR $\left(100 \mathrm{MHz}, \mathrm{CDCl}_{3}\right) \delta 158.3,132.3,132.0,131.6,131.3,129.9,128.1$, $125.4,122.7,120.0,119.0,117.0,112.5,75.4,29.1,19.1,9.7$ (observed complexity due to P-C splitting). IR (neat, $\mathrm{cm}^{-1}$ ) 2977, 1591, 1492, 1454, 1328, 1235, 1168, 1127, 1066 , 785, 698. Anal. Calcd for $\mathrm{C}_{11} \mathrm{H}_{13} \mathrm{~F}_{3} \mathrm{O}$ : C, 60.54; H, 6.00. Found: C, 60.57; H, 6.14.

\section{1-(1,3-Dimethylbut-2-enyloxy)-3-trifluoromethylbenzene (2j)}

The general procedure was followed using $\mathrm{Pd}(\mathrm{OAc})_{2}(4.5 \mathrm{mg}, 0.02 \mathrm{mmol}), \mathbf{L 1 0}$ (11.4 mg, $0.024 \mathrm{mmol}), \mathrm{Cs}_{2} \mathrm{CO}_{3}(391 \mathrm{mg}, 1.2 \mathrm{mmol}$ ), 1-chloro-3-trifluoromethylbenzene (181 mg, $1 \mathrm{mmol})$, 4-methylpent-3-en-2-ol (200 mg, $2 \mathrm{mmol})$ with toluene $(2 \mathrm{~mL})$ as solvent for 8 h at $50{ }^{\circ} \mathrm{C}$. Chromatographic purification (hexane) provided $\mathbf{2} \mathbf{j}$ (colorless liquid, $201 \mathrm{mg}$, $82 \%) .{ }^{1} \mathrm{H}$ NMR $\left(400 \mathrm{MHz}, \mathrm{CDCl}_{3}\right) \delta 7.34(\mathrm{t}, 1 \mathrm{H}, \mathrm{J}=8.1 \mathrm{~Hz}), 7.15(\mathrm{~d}, 1 \mathrm{H}, \mathrm{J}=7.6 \mathrm{~Hz})$, 
$7.08(\mathrm{~s}, 1 \mathrm{H}), 7.01(\mathrm{dd}, 1 \mathrm{H}, \mathrm{J}=8.3,2.6 \mathrm{~Hz}), 5.15-5.20(\mathrm{~m}, 1 \mathrm{H}), 4.98-5.05(\mathrm{~m}, 1 \mathrm{H}), 1.75$

$(\mathrm{d}, 3 \mathrm{H}, \mathrm{J}=1.3 \mathrm{~Hz}), 1.72(\mathrm{~d}, 3 \mathrm{H}, \mathrm{J}=1.3 \mathrm{~Hz}), 1.40(\mathrm{~d}, 3 \mathrm{H}, \mathrm{J}=6.2 \mathrm{~Hz}) .{ }^{13} \mathrm{C}$ NMR $(100$ $\left.\mathrm{MHz}, \mathrm{CDCl}_{3}\right) \delta 158.2,135.1,132.0,131.7,131.4,131.1,129.7,128.1,126.2,125.4$ 122.7, 120.0, 119.2, 117.0, 112.6, 71.7, 25.6, 21.3, 18.2. IR (neat, $\mathrm{cm}^{-1}$ ) 2979, 1591, 1491, 1450, 1336, 1235, 1127, 1065, 960, 792. Anal. Calcd for $\mathrm{C}_{13} \mathrm{H}_{15} \mathrm{~F}_{3} \mathrm{O}: \mathrm{C}, 63.93 ; \mathrm{H}$, 6.19. Found: C, 64.16; H, 6.42 .

\section{3-(1,2,2-Trimethylpropoxy)-biphenyl (2k)}

The general procedure was followed using $\mathrm{Pd}(\mathrm{OAc})_{2}(4.5 \mathrm{mg}, 0.02 \mathrm{mmol}), \mathbf{L 1 0}$ (11.4 mg, $0.024 \mathrm{mmol}), \mathrm{Cs}_{2} \mathrm{CO}_{3}$ (489 mg, $1.5 \mathrm{mmol}$ ), 3-bromobiphenyl (233 mg, $1 \mathrm{mmol}$ ), 3,3dimethylbutan-2-ol (204 mg, $2 \mathrm{mmol})$ with $\mathrm{Bu}_{3} \mathrm{~N}(1 \mathrm{~mL})$ as solvent for $24 \mathrm{~h}$ at $90{ }^{\circ} \mathrm{C}$. The filtrate was extracted with $10 \% \mathrm{HCl}(2 \times 20 \mathrm{~mL})$. Chromatographic purification (hexane, followed by $1 \%$ ethyl acetate in hexane) provided $\mathbf{2 k}$ (colorless liquid, $158 \mathrm{mg}, 62 \%$ ).

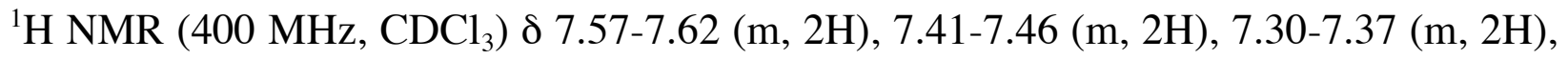
7.11-7.16 (m, 2H), $6.89(\mathrm{ddd}, 1 \mathrm{H}, \mathrm{J}=8.2,2.5,1.0 \mathrm{~Hz}), 4.08(\mathrm{q}, 1 \mathrm{H}, \mathrm{J}=6.4 \mathrm{~Hz}), 1.24(\mathrm{~d}$, $3 \mathrm{H}, \mathrm{J}=6.3 \mathrm{~Hz}), 1.01(\mathrm{~s}, 9 \mathrm{H}) .{ }^{13} \mathrm{C} \mathrm{NMR}\left(125 \mathrm{MHz}, \mathrm{CDCl}_{3}\right) \delta 159.2,142.7,141.2,129.7$, 128.6, 127.3, 127.2, 119.2, 114.9, 114.5, 81.3, 35.1, 25.9, 14.2. IR (neat, $\mathrm{cm}^{-1}$ ) 2960, 1597, 1477, 1420, 1375, 1295, 1202, 1079, 1008, 931, 757. Anal. Calcd for $\mathrm{C}_{18} \mathrm{H}_{22} \mathrm{O}: \mathrm{C}$, 84.99; H, 8.72. Found: C, 85.05; H, 8.84.

\section{3-(1,3-Dimethylbut-2-enyloxy)-biphenyl (2l)}


The general procedure was followed using $\mathrm{Pd}(\mathrm{OAc})_{2}(4.5 \mathrm{mg}, 0.02 \mathrm{mmol}), \mathbf{L 1 0}$ (11.4 mg, $0.024 \mathrm{mmol}), \mathrm{Cs}_{2} \mathrm{CO}_{3}(489 \mathrm{mg}, 1.5 \mathrm{mmol}), 3$-bromobiphenyl (233 mg, $\left.1 \mathrm{mmol}\right), 4-$ methylpent-3-en-2-ol $(200 \mathrm{mg}, 2 \mathrm{mmol})$ with $\mathrm{Bu}_{3} \mathrm{~N}(2 \mathrm{~mL})$ as solvent for $18 \mathrm{~h}$ at $50{ }^{\circ} \mathrm{C}$. The filtrate was extracted with $10 \% \mathrm{HCl}(2 \times 35 \mathrm{~mL})$. Chromatographic purification (1 $\%$ ethyl acetate in hexane) provided $2 \mathrm{l}$ (colorless liquid, $209 \mathrm{mg}, 83 \%$ ). ${ }^{1} \mathrm{H}$ NMR (400 $\left.\mathrm{MHz}, \mathrm{CDCl}_{3}\right) \delta$ 7.55-7.58 (m, 2H), 7.40-7.45 (m, 2H), 7.29-7.36 (m, 2H), 7.13-7.16 (m, 1H), 7.10-7.12 (m, 1H), $6.85(\mathrm{ddd}, 1 \mathrm{H}, \mathrm{J}=8.2,2.6,1.0 \mathrm{~Hz}), 5.24-5.28(\mathrm{~m}, 1 \mathrm{H}), 5.02-5.10$ $(\mathrm{m}, 1 \mathrm{H}), 1.75(\mathrm{~d}, 3 \mathrm{H}, \mathrm{J}=1.3 \mathrm{~Hz}), 1.73(\mathrm{~d}, 3 \mathrm{H}, \mathrm{J}=1.3 \mathrm{~Hz}), 1.41(\mathrm{~d}, 3 \mathrm{H}, \mathrm{J}=6.3 \mathrm{~Hz}) \cdot{ }^{13} \mathrm{C}$ $\operatorname{NMR}\left(125 \mathrm{MHz}, \mathrm{CDCl}_{3}\right) \delta 158.4,142.5,141.2,134.4,129.6,128.7,127.2,127.1,127.0$ 119.4, 114.8, 114.5, 71.2, 25.7, 21.4, 18.3. IR (neat, $\left.\mathrm{cm}^{-1}\right)$ 2975, 2930, 1597, 1477, 1420, 1294, 1202, 1064, 757, 698. Anal. Calcd for $\mathrm{C}_{18} \mathrm{H}_{20} \mathrm{O}$ : C, 85.67; H, 7.99. Found: $\mathrm{C}$, $85.65 ; \mathrm{H}, 8.07$.

\section{1-sec-butoxy-3-methoxybenzene (2m)}

The general procedure was followed using $\mathrm{Pd}(\mathrm{OAc})_{2}(4.5 \mathrm{mg}, 0.02 \mathrm{mmol}), \mathbf{L 1 0}$ (11.4 mg, $0.024 \mathrm{mmol}), \mathrm{Cs}_{2} \mathrm{CO}_{3}(489 \mathrm{mg}, 1.5 \mathrm{mmol}), 1$-bromo-3-methoxybenzene (187 mg, 1 mmol), 2-butanol $(148 \mathrm{mg}, 2 \mathrm{mmol})$ with $\mathrm{Bu}_{3} \mathrm{~N}(1 \mathrm{~mL})$ as solvent for $24 \mathrm{~h}$ at $90{ }^{\circ} \mathrm{C}$. The filtrate was extracted with $10 \% \mathrm{HCl}(2 \times 20 \mathrm{~mL})$. Chromatographic purification $(2 \%$ ethyl acetate in hexane) provided $\mathbf{2 m}$ (colorless liquid, $114 \mathrm{mg}, 63 \%) .{ }^{1} \mathrm{H}$ NMR (400 $\left.\mathrm{MHz}, \mathrm{CDCl}_{3}\right) \delta 7.16(\mathrm{t}, 1 \mathrm{H}), 6.45-6.51(\mathrm{~m}, 3 \mathrm{H}), 4.28($ sextet, $1 \mathrm{H}, \mathrm{J}=6.2 \mathrm{~Hz}), 3.79(\mathrm{~s}$, $3 \mathrm{H}), 1.69-1.80(\mathrm{~m}, 1 \mathrm{H}), 1.56-1.67(\mathrm{~m}, 1 \mathrm{H}), 1.29(\mathrm{~d}, 3 \mathrm{H}, \mathrm{J}=6.1 \mathrm{~Hz}), 0.97(\mathrm{t}, 3 \mathrm{H}, \mathrm{J}=7.5$ 
$\mathrm{Hz}) .{ }^{13} \mathrm{C} \mathrm{NMR}\left(100 \mathrm{MHz}, \mathrm{CDCl}_{3}\right) \delta 160.8,159.4,129.8,107.9,105.9,102.2,74.9,55.1$, 29.1, 19.2, 9.8. IR (neat, $\mathrm{cm}^{-1}$ ) 2972, 1601, 1492, 1377, 1286, 1201, 1150, 1043, 1001, 837, 763, 688. Anal. Calcd for $\mathrm{C}_{11} \mathrm{H}_{16} \mathrm{O}_{2}$ : C, 73.30; H, 8.95. Found: C, 73.44; H, 9.11.

\section{1-(1,3-Dimethylbut-2-enyloxy)-3-methoxylbenzene (2n)}

The general procedure was followed using $\mathrm{Pd}(\mathrm{OAc})_{2}$ (4.5 mg, $\left.0.02 \mathrm{mmol}\right), \mathbf{L 1 0}$ (11.4 mg, $0.024 \mathrm{mmol}), \mathrm{Cs}_{2} \mathrm{CO}_{3}(489 \mathrm{mg}, 1.5 \mathrm{mmol}), 1$-bromo-3-methoxybenzene (187 mg, 1 mmol), 4-methylpent-3-en-2-ol (200 mg, $2 \mathrm{mmol})$ with toluene ( $2 \mathrm{~mL})$ as solvent for $18 \mathrm{~h}$ at $50{ }^{\circ} \mathrm{C}$. Chromatographic purification ( $2 \%$ ethyl acetate in hexane) provided $\mathbf{2 n}$ (colorless liquid, $187 \mathrm{mg}, 91 \%) .{ }^{1} \mathrm{H}$ NMR $\left(400 \mathrm{MHz}, \mathrm{CDCl}_{3}\right) \delta 7.14(\mathrm{t}, 1 \mathrm{H}, \mathrm{J}=8.2 \mathrm{~Hz})$, 6.42-6.51 (m, 3H), 5.19-5.25 (m, 1H), 4.94-5.02 (m, 1H), $3.77(\mathrm{~s}, 3 \mathrm{H}), 1.73(\mathrm{~d}, 3 \mathrm{H}, \mathrm{J}=$ $1.3 \mathrm{~Hz}), 1.72(\mathrm{~d}, 3 \mathrm{H}, \mathrm{J}=1.3 \mathrm{~Hz}), 1.37(\mathrm{~d}, 3 \mathrm{H}, \mathrm{J}=6.3 \mathrm{~Hz}) \cdot{ }^{13} \mathrm{C} \mathrm{NMR}\left(125 \mathrm{MHz}, \mathrm{CDCl}_{3}\right) \delta$ $160.6,159.3,134.2,129.6,126.9,107.9,106.0,102.0,71.1,55.1,25.6,21.3,18.2$. IR $\left(\right.$ neat, $\left.\mathrm{cm}^{-1}\right)$ 2975, 1599, 1491, 1452, 1284, 1263, 1200, 1152, 1044, 976, 834, 762, 687. Anal. Calcd for $\mathrm{C}_{13} \mathrm{H}_{18} \mathrm{O}_{2}$ : C, 75.69; H, 8.80. Found: C, 75.39; H, 8.87.

\section{1-Methoxy-3-(1-vinylbutoxy)-benzene (2o)}

The general procedure was followed using $\mathrm{Pd}(\mathrm{OAc})_{2}(11.2 \mathrm{mg}, 0.05 \mathrm{mmol}), \mathbf{L 1 0}$ (28.4 $\mathrm{mg}, 0.06 \mathrm{mmol}), \mathrm{Cs}_{2} \mathrm{CO}_{3}(489 \mathrm{mg}, 1.5 \mathrm{mmol}), 1$-bromo-3-methoxybenzene (187 mg, 1 mmol), hex-1-en-3-ol (120 mg, $1.2 \mathrm{mmol})$ with $\mathrm{Bu}_{3} \mathrm{~N}(2 \mathrm{~mL})$ as solvent for $18 \mathrm{~h}$ at $70{ }^{\circ} \mathrm{C}$. The filtrate was extracted with $10 \% \mathrm{HCl}(2 \times 35 \mathrm{~mL})$. Chromatographic purification (1.5 $\%$ ethyl acetate in hexane) provided 20 (colorless liquid, $129 \mathrm{mg}, 63 \%) .{ }^{1} \mathrm{H}$ NMR (400 
$\left.\mathrm{MHz}, \mathrm{CDCl}_{3}\right) \delta 7.14(\mathrm{t}, 1 \mathrm{H}), 6.46-6.54(\mathrm{~m}, 3 \mathrm{H}), 5.84(\mathrm{ddd}, 1 \mathrm{H}, \mathrm{J}=17.4,10.6,6.3 \mathrm{~Hz})$ $5.25(\mathrm{dt}, 1 \mathrm{H}, \mathrm{J}=17.4,1.2 \mathrm{~Hz}), 5.19(\mathrm{dt}, 1 \mathrm{H}, \mathrm{J}=10.6,1.2 \mathrm{~Hz}), 4.56-4.63(\mathrm{~m}, 1 \mathrm{H}), 3.78(\mathrm{~s}$, $3 \mathrm{H}), 1.72-1.83(\mathrm{~m}, 1 \mathrm{H}), 1.58-1.68(\mathrm{~m}, 1 \mathrm{H}), 1.37-1.57(\mathrm{~m}, 2 \mathrm{H}), 0.95(\mathrm{t}, 3 \mathrm{H}, \mathrm{J}=7.4 \mathrm{~Hz})$. ${ }^{13} \mathrm{C}$ NMR $\left(100 \mathrm{MHz}, \mathrm{CDCl}_{3}\right) \delta 160.6,159.6,138.1,129.6,116.2,108.1,106.1,102.2$, 78.7, 55.1, 37.6, 18.5, 13.9. IR (neat, $\left.\mathrm{cm}^{-1}\right)$ 2960, 1600, 1491, 1284, 1200, 1151, 1044, 989, 926, 836, 762, 687. Anal. Calcd for $\mathrm{C}_{13} \mathrm{H}_{18} \mathrm{O}_{2}$ : C, 75.69; H, 8.80. Found: C, 75.68; $\mathrm{H}, 8.85$.

\section{1-sec-butoxy-2,5-dimethylbenzene (2p)}

The general procedure was followed using $\mathrm{Pd}(\mathrm{OAc})_{2}(4.5 \mathrm{mg}, 0.02 \mathrm{mmol}), \mathbf{L 1 1}$ (10.0 mg, $0.024 \mathrm{mmol}), \mathrm{Cs}_{2} \mathrm{CO}_{3}$ (489 mg, $1.5 \mathrm{mmol}$ ), bromo- -xylene (185 mg, $1 \mathrm{mmol}$ ), 2-butanol (148 mg, $2 \mathrm{mmol})$ with toluene $(2 \mathrm{~mL})$ as solvent for $24 \mathrm{~h}$ at $90{ }^{\circ} \mathrm{C}$. Chromatographic purification ( $0.5 \%$ ethyl acetate in hexane) provided $\mathbf{2 p}$ (colorless liquid, $82 \mathrm{mg}, 46 \%)$.

${ }^{1} \mathrm{H}$ NMR $\left(400 \mathrm{MHz}, \mathrm{CDCl}_{3}\right) \delta 7.01(\mathrm{~d}, 1 \mathrm{H}, \mathrm{J}=8.0 \mathrm{~Hz}), 6.63-6.66(\mathrm{~m}, 2 \mathrm{H}), 4.28$ (sextet, $1 \mathrm{H}, \mathrm{J}=6.0 \mathrm{~Hz}), 2.30(\mathrm{~s}, 3 \mathrm{H}), 2.17(\mathrm{~s}, 3 \mathrm{H}), 1.69-1.80(\mathrm{~m}, 1 \mathrm{H}), 1.58-1.68(\mathrm{~m}, 1 \mathrm{H}), 1.28(\mathrm{~d}$, $3 \mathrm{H}), 0.98(\mathrm{t}, 3 \mathrm{H}) .{ }^{13} \mathrm{C} \mathrm{NMR}\left(100 \mathrm{MHz}, \mathrm{CDCl}_{3}\right) \delta 156.2,136.2,130.4,124.6,120.5$, 113.7, 74.9, 29.4, 21.4, 19.4, 16.0, 9.8. IR (neat, $\mathrm{cm}^{-1}$ ) 2971, 2925, 1584, 1507, 1462, 1412, 1378, 1263, 1129, 1004, 802. Anal. Calcd for $\mathrm{C}_{12} \mathrm{H}_{18} \mathrm{O}: \mathrm{C}, 80.85 ; \mathrm{H}, 10.18$. Found: C, 80.91; H, 10.27.

\section{1-(1,3-Dimethylbut-2-enyloxy)-2,5-dimethylbenzene (2q)}


The general procedure was followed using $\mathrm{Pd}(\mathrm{OAc})_{2}(4.5 \mathrm{mg}, 0.02 \mathrm{mmol}), \mathbf{L 1 1}$ (10.0 mg, $0.024 \mathrm{mmol}), \mathrm{Cs}_{2} \mathrm{CO}_{3}(489 \mathrm{mg}, 1.5 \mathrm{mmol})$, bromo- $p$-xylene $(185 \mathrm{mg}, 1 \mathrm{mmol}), 4-$ methylpent-3-en-2-ol (200 mg, $2 \mathrm{mmol})$ with $\mathrm{Bu}_{3} \mathrm{~N}(2 \mathrm{~mL})$ as solvent for $18 \mathrm{~h}$ at $70{ }^{\circ} \mathrm{C}$. The filtrate was extracted with $10 \% \mathrm{HCl}(2 \times 35 \mathrm{~mL})$. Chromatographic purification (1 \% ethyl acetate in hexane) provided 2q (colorless liquid, $123 \mathrm{mg}, 60 \%$ ). ${ }^{1} \mathrm{H}$ NMR (400 $\left.\mathrm{MHz}, \mathrm{CDCl}_{3}\right) \delta 6.99(\mathrm{~d}, 1 \mathrm{H}, \mathrm{J}=7.5 \mathrm{~Hz}), 6.64(\mathrm{~d}, 1 \mathrm{H}, \mathrm{J}=7.5 \mathrm{~Hz}), 6.61(\mathrm{~s}, 1 \mathrm{H}), 5.21-5.26$ (m, 1H), 4.91-4.99 (m, 1H), $2.28(\mathrm{~s}, 3 \mathrm{H}), 2.17(\mathrm{~s}, 3 \mathrm{H}), 1.71(\mathrm{~s}, 6 \mathrm{H}), 1.36(\mathrm{~d}, 3 \mathrm{H}, \mathrm{J}=6.3$ $\mathrm{Hz}) .{ }^{13} \mathrm{C} \mathrm{NMR}\left(125 \mathrm{MHz}, \mathrm{CDCl}_{3}\right) \delta 156.2,136.0,133.6,130.2,127.5,124.4,120.7$, 114.4, 71.4, 25.6, 21.5, 21.4, 18.2, 16.0. IR (neat, $\left.\mathrm{cm}^{-1}\right)$ 2976, 1614, 1584, 1507, 1448, 1376, 1261, 1127, 1064, 1001, 802. Anal. Calcd for $\mathrm{C}_{14} \mathrm{H}_{20} \mathrm{O}: \mathrm{C}, 82.30 ; \mathrm{H}, 9.87$. Found: C, 82.08; H, 9.93.

\section{(2,4,4-Trimethylcyclohex-2-enyloxy)-benzene (2r)}

The general procedure was followed using $\mathrm{Pd}(\mathrm{OAc})_{2}(4.5 \mathrm{mg}, 0.02 \mathrm{mmol}), \mathbf{L 1 0}(11.4 \mathrm{mg}$, $0.024 \mathrm{mmol}), \mathrm{Cs}_{2} \mathrm{CO}_{3}(489 \mathrm{mg}, 1.5 \mathrm{mmol})$, bromobenzene (157 mg, $\left.1 \mathrm{mmol}\right), 2,4,4-$ trimethylcyclohex-2-enol (280 $\mathrm{mg}, 2 \mathrm{mmol})$ with toluene $(2 \mathrm{~mL})$ as solvent for $24 \mathrm{~h}$ at 70 ${ }^{\circ} \mathrm{C}$. Chromatographic purification $(0.5 \%$ ethyl acetate in hexane) provided $\mathbf{2 r}$ (colorless liquid, $180 \mathrm{mg}, 84 \%) .{ }^{1} \mathrm{H}$ NMR (400 MHz, $\left.\mathrm{CDCl}_{3}\right) \delta$ 7.26-7.31 (m, 2H), 6.91-6.98 (m, 3H), $5.42(\mathrm{~s}, 1 \mathrm{H}), 4.52(\mathrm{t}, 1 \mathrm{H}, \mathrm{J}=4.3 \mathrm{~Hz}), 1.82-1.99(\mathrm{~m}, 2 \mathrm{H}), 1.77(\mathrm{~s}, 3 \mathrm{H}), 1.61(\mathrm{ddd}, 1 \mathrm{H}$, $\mathrm{J}=13.3,11.0,3.7 \mathrm{~Hz}), 1.37(\mathrm{ddd}, 1 \mathrm{H}, \mathrm{J}=13.1,6.6,3.3 \mathrm{~Hz}), 1.05(\mathrm{~s}, 3 \mathrm{H}), 0.97(\mathrm{~s}, 3 \mathrm{H})$. ${ }^{13} \mathrm{C} \mathrm{NMR}\left(100 \mathrm{MHz}, \mathrm{CDCl}_{3}\right) \delta 158.6,137.5,130.3,129.4,120.6,116.0,74.2,32.5,32.0$, 
30.0, 28.0, 24.8, 20.8. IR (neat, $\mathrm{cm}^{-1}$ ) 2955, 1597, 1493, 1360, 1297, 1237, 1171, 1032, 1002, 966, 880, 752, 692. Anal. Calcd for $\mathrm{C}_{15} \mathrm{H}_{20} \mathrm{O}$ : C, 83.28; H, 9.32. Found: C, 83.42; H, 9.42 .

\section{3-sec-Butoxybenzoic acid tert-butyl ester (2s)}

The general procedure was followed using $\mathrm{Pd}(\mathrm{OAc})_{2}(4.5 \mathrm{mg}, 0.02 \mathrm{mmol}), \mathbf{L 1 0}$ (11.4 mg, $0.024 \mathrm{mmol}), \mathrm{Cs}_{2} \mathrm{CO}_{3}(489 \mathrm{mg}, 1.5 \mathrm{mmol}), 3$-bromobenzoic acid tert-butyl ester ${ }^{13}$ (257 $\mathrm{mg}, 1 \mathrm{mmol})$, 2-butanol (148 mg, $2 \mathrm{mmol})$ with $\mathrm{Bu}_{3} \mathrm{~N}(2 \mathrm{~mL})$ as solvent for $24 \mathrm{~h}$ at $90{ }^{\circ} \mathrm{C}$. The filtrate was extracted with $10 \% \mathrm{HCl}(2 \times 35 \mathrm{~mL})$. Chromatographic purification (1.5

$\%$ ethyl acetate in hexane) provided 2 s (colorless liquid, $203 \mathrm{mg}, 81 \%$ ). ${ }^{1} \mathrm{H}$ NMR (400 $\left.\mathrm{MHz}, \mathrm{CDCl}_{3}\right) \delta 7.55(\mathrm{dt}, 1 \mathrm{H}, \mathrm{J}=7.8,1.3 \mathrm{~Hz}), 7.51(\mathrm{dd}, 1 \mathrm{H}, \mathrm{J}=2.6,1.5 \mathrm{~Hz}), 7.30(\mathrm{t}, 1 \mathrm{H}$, $\mathrm{J}=7.9 \mathrm{~Hz}), 7.05(\mathrm{ddd}, 1 \mathrm{H}, \mathrm{J}=8.3,2.6,1.0 \mathrm{~Hz}), 4.35($ sextet, $1 \mathrm{H}, \mathrm{J}=6.0 \mathrm{~Hz}), 1.70-1.81$

$(\mathrm{m}, 1 \mathrm{H}), 1.59-1.69(\mathrm{~m}, 1 \mathrm{H}), 1.59(\mathrm{~s}, 9 \mathrm{H}), 1.30(\mathrm{~d}, 3 \mathrm{H}, \mathrm{J}=6.1 \mathrm{~Hz}), 0.98(\mathrm{t}, 3 \mathrm{H}, \mathrm{J}=7.5$ Hz). ${ }^{13} \mathrm{C}$ NMR (100 MHz, $\left.\mathrm{CDCl}_{3}\right) \delta$ 165.6, 158.0, 133.2, 129.1, 121.4, 120.3, 116.1, 80.8, 75.1, 29.0, 28.1, 19.1, 9.7. IR (neat, $\mathrm{cm}^{-1}$ ) 2976, 1716, 1584, 1440, 1294, 1171, 1003, 952, 757, 685. Anal. Calcd for $\mathrm{C}_{15} \mathrm{H}_{22} \mathrm{O}_{3}$ : C, 71.97; H, 8.86. Found: C, 71.86; H, 8.81.

\section{3-(1,3-Dimethylbut-2-enyloxy)-benzoic acid tert-butyl ester (2t)}

The general procedure was followed using $\mathrm{Pd}(\mathrm{OAc})_{2}(4.5 \mathrm{mg}, 0.02 \mathrm{mmol}), \mathbf{L 1 0}$ (11.4 mg, $0.024 \mathrm{mmol}), \mathrm{Cs}_{2} \mathrm{CO}_{3}(489 \mathrm{mg}, 1.5 \mathrm{mmol}$ ), 3-bromobenzoic acid tert-butyl ester ( $257 \mathrm{mg}$, $1 \mathrm{mmol})$, 4-methylpent-3-en-2-ol (200 mg, $2 \mathrm{mmol})$ with toluene (2 mL) as solvent for 18 $\mathrm{h}$ at $50{ }^{\circ} \mathrm{C}$. Chromatographic purification (2\% ethyl acetate in hexane) provided $\mathbf{2 t}$ 
(colorless liquid, $254 \mathrm{mg}, 92 \%) .{ }^{1} \mathrm{H} \mathrm{NMR}\left(400 \mathrm{MHz}, \mathrm{CDCl}_{3}\right) \delta 7.55(\mathrm{dt}, 1 \mathrm{H}, \mathrm{J}=7.7,1.3$ $\mathrm{Hz}), 7.48(\mathrm{dd}, 1 \mathrm{H}, \mathrm{J}=2.5,1.5 \mathrm{~Hz}), 7.28(\mathrm{t}, 1 \mathrm{H}, \mathrm{J}=8.0 \mathrm{~Hz}), 7.02(\mathrm{ddd}, 1 \mathrm{H}, \mathrm{J}=8.2,2.7$, $1.0 \mathrm{~Hz}), 5.18-5.22(\mathrm{~m}, 1 \mathrm{H}), 5.00-5.08(\mathrm{~m}, 1 \mathrm{H}), 1.76(\mathrm{~d}, 3 \mathrm{H}, \mathrm{J}=1.3 \mathrm{~Hz}), 1.72(\mathrm{~d}, 3 \mathrm{H}, \mathrm{J}=$ $1.3 \mathrm{~Hz}), 1.58(\mathrm{~s}, 9 \mathrm{H}), 1.39(\mathrm{~d}, 3 \mathrm{H}, \mathrm{J}=6.3 \mathrm{~Hz}) .{ }^{13} \mathrm{C} \mathrm{NMR}\left(100 \mathrm{MHz}, \mathrm{CDCl}_{3}\right) \delta$ 165.6, $157.9,134.7,133.1,129.0,126.5,121.5,120.4,116.0,80.8,71.3,28.1,25.6,21.3,18.3$. IR (neat, $\left.\mathrm{cm}^{-1}\right)$ 2977, 1714, 1583, 1485, 1441, 1369, 1294, 1107, 1000, 969, 851, 757, 683. Anal. Calcd for $\mathrm{C}_{17} \mathrm{H}_{24} \mathrm{O}_{3}: \mathrm{C}, 73.88 ; \mathrm{H}, 8.75$. Found: C, 73.83; H, 8.88.

\section{5-sec-Butoxy-1-tosylindole (2u)}

The general procedure was followed using $\mathrm{Pd}(\mathrm{OAc})_{2}(11.2 \mathrm{mg}, 0.05 \mathrm{mmol}), \mathbf{L 1 0}$ (28.4 $\mathrm{mg}, 0.06 \mathrm{mmol}$ ), $\mathrm{Cs}_{2} \mathrm{CO}_{3}$ (489 mg, $1.5 \mathrm{mmol}$ ), 5-bromo-1-tosylindole ${ }^{14}$ (350 mg, 1 mmol), 2-butanol (148 mg, $2 \mathrm{mmol})$ with $\mathrm{Bu}_{3} \mathrm{~N}(2 \mathrm{~mL})$ as solvent for $24 \mathrm{~h}$ at $90{ }^{\circ} \mathrm{C}$. The filtrate was concentrated and $\mathrm{Bu}_{3} \mathrm{~N}$ was distilled out in vacuo. Chromatographic piurification $\left(2: 1\right.$ hexane : $\mathrm{CH}_{2} \mathrm{Cl}_{2}$, followed by $1: 1$ hexane $: \mathrm{CH}_{2} \mathrm{Cl}_{2}$ ) provided $\mathbf{2 u}$ (colorless oil, $244 \mathrm{mg}, 71 \%$ ). Crystallized on storage to give the colorless crystals. M.p. $80-81{ }^{\circ} \mathrm{C} .{ }^{1} \mathrm{H}$ NMR $\left(400 \mathrm{MHz}, \mathrm{CDCl}_{3}\right) \delta 7.86(\mathrm{~d}, 1 \mathrm{H}, \mathrm{J}=8.9 \mathrm{~Hz}), 7.73(\mathrm{~d}, 2 \mathrm{H}, \mathrm{J}=8.5$ $\mathrm{Hz}), 7.50(\mathrm{~d}, 1 \mathrm{H}, \mathrm{J}=3.7 \mathrm{~Hz}), 7.19(\mathrm{~d}, 2 \mathrm{H}, \mathrm{J}=8.4 \mathrm{~Hz}), 6.96(\mathrm{~d}, 1 \mathrm{H}, \mathrm{J}=2.4 \mathrm{~Hz}), 6.91(\mathrm{dd}$, $1 \mathrm{H}, \mathrm{J}=9.0,2.5 \mathrm{~Hz}), 6.55(\mathrm{dd}, 1 \mathrm{H}, \mathrm{J}=3.7,0.7 \mathrm{~Hz}), 4.25($ sextet, $1 \mathrm{H}, \mathrm{J}=6.1 \mathrm{~Hz}), 2.32(\mathrm{~s}$, $3 \mathrm{H}), 1.68-1.79(\mathrm{~m}, 1 \mathrm{H}), 1.54-1.65(\mathrm{~m}, 1 \mathrm{H}), 1.27(\mathrm{~d}, 3 \mathrm{H}, \mathrm{J}=6.1 \mathrm{~Hz}), 0.96(\mathrm{t}, 3 \mathrm{H}) .{ }^{13} \mathrm{C}$ NMR $\left(100 \mathrm{MHz}, \mathrm{CDCl}_{3}\right) \delta 154.8,144.7,135.2,131.7,129.8,129.4,126.9,126.7,115.4$ 114.3, 109.1, 106.4, 75.8, 29.1, 21.5, 19.2, 9.8. IR (neat, $\mathrm{cm}^{-1}$ ) 2973, 1597, 1458, 1371, 
1223, 1151, 996, 813, 676. Anal. Calcd for $\mathrm{C}_{19} \mathrm{H}_{21} \mathrm{NO}_{3} \mathrm{~S}$ : C, 66.45; H, 6.16. Found: C, 66.31; H, 6.15.

\section{5-(1,3-Dimethylbut-2-enyloxy)-1-tosylindole (2v)}

The general procedure was followed using $\mathrm{Pd}(\mathrm{OAc})_{2}(11.2 \mathrm{mg}, 0.05 \mathrm{mmol}), \mathbf{L 1 0}$ (28.4 mg, $0.06 \mathrm{mmol}$ ), $\mathrm{Cs}_{2} \mathrm{CO}_{3}$ (489 mg, $1.5 \mathrm{mmol}$ ), 5-bromo-1-tosylindole (350 mg, $1 \mathrm{mmol}$ ), 4-methylpent-3-en-2-ol (200 mg, $2 \mathrm{mmol})$ with touene $(2 \mathrm{~mL})$ as solvent for $18 \mathrm{~h}$ at 50 ${ }^{\circ} \mathrm{C}$. Chromatographic purification $\left(2: 1\right.$ hexane $: \mathrm{CH}_{2} \mathrm{Cl}_{2}$, followed by $1: 1$ hexane : $\mathrm{CH}_{2} \mathrm{Cl}_{2}$ ) provided $\mathbf{2 v}$ (colorless oil, $281 \mathrm{mg}, 76 \%$ ). Crystallized from ethanol to give the colorless crystals. M.p. $102-103{ }^{\circ} \mathrm{C} .{ }^{1} \mathrm{H}$ NMR $\left(400 \mathrm{MHz}, \mathrm{CDCl}_{3}\right) \delta 7.84(\mathrm{~d}, 1 \mathrm{H}, \mathrm{J}=8.9$ Hz), $7.73(\mathrm{~d}, 2 \mathrm{H}, \mathrm{J}=8.4 \mathrm{~Hz}), 7.49(\mathrm{~d}, 1 \mathrm{H}, \mathrm{J}=3.7 \mathrm{~Hz}), 7.20(\mathrm{~d}, 2 \mathrm{H}, \mathrm{J}=8.4 \mathrm{~Hz}), 6.92(\mathrm{~d}$, $1 \mathrm{H}, \mathrm{J}=2.2 \mathrm{~Hz}), 6.89(\mathrm{dd}, 1 \mathrm{H}, \mathrm{J}=8.9,2.5 \mathrm{~Hz}), 6.54(\mathrm{dd}, 1 \mathrm{H}, \mathrm{J}=3.7,0.8 \mathrm{~Hz}), 5.19-5.24$ (m, 1H), 4.91-4.98 (m, 1H), $2.33(\mathrm{~s}, 3 \mathrm{H}), 1.701(\mathrm{~s}, 3 \mathrm{H}), 1.697(\mathrm{~s}, 3 \mathrm{H}), 1.36(\mathrm{~d}, 3 \mathrm{H}, \mathrm{J}=$ $6.3 \mathrm{~Hz}) .{ }^{13} \mathrm{C}$ NMR $\left(100 \mathrm{MHz}, \mathrm{CDCl}_{3}\right) \delta 154.7,144.7,135.2,134.4,131.6,129.7,129.5$, 127.0, 126.8, 126.7, 115.3, 114.2, 109.2, 106.4, 71.9, 25.6, 21.5, 21.3, 18.2. IR (neat, $\mathrm{cm}^{-}$

1) $3119,2983,1610,1459,1371,1226,1157,816,719,673$. Anal. Calcd for $\mathrm{C}_{21} \mathrm{H}_{23} \mathrm{NO}_{3} \mathrm{~S}: \mathrm{C}, 68.27 ; \mathrm{H}, 6.27$. Found: C, 68.11; H, 6.25.

\section{1-Butoxy-3,5-dimethylbenzene (12a)}

The general procedure was followed using $\mathrm{Pd}(\mathrm{OAc})_{2}(4.5 \mathrm{mg}, 0.02 \mathrm{mmol}), \mathbf{L 6}$ (10.7 mg, $0.024 \mathrm{mmol}), \mathrm{Cs}_{2} \mathrm{CO}_{3}(489 \mathrm{mg}, 1.5 \mathrm{mmol}), 5$-bromo- $m$-xylene (185 mg, $\left.1 \mathrm{mmol}\right)$, butanol (148 mg, $2 \mathrm{mmol})$ with $\mathrm{Bu}_{3} \mathrm{~N}(2 \mathrm{~mL})$ as solvent for $18 \mathrm{~h}$ at $70{ }^{\circ} \mathrm{C}$. The filtrate was 
extracted with $10 \% \mathrm{HCl}(2 \times 35 \mathrm{~mL})$. Chromatographic purification (hexane, followed by $2 \%$ ethyl acetate in hexane) provided $\mathbf{1 2 a ^ { 4 }}$ (colorless liquid, $161 \mathrm{mg}, 90 \%$ ). ${ }^{1} \mathrm{H}$ and ${ }^{13} \mathrm{C}$ NMR data were consistent with those of the previously reported compound.

\section{1-Benzyloxy-3,5-dimethylbenzene (12b)}

The general procedure was followed using $\mathrm{Pd}(\mathrm{OAc})_{2}(4.5 \mathrm{mg}, 0.02 \mathrm{mmol}), \mathbf{L 6}$ (10.7 $\mathrm{mg}$, $0.024 \mathrm{mmol}), \mathrm{Cs}_{2} \mathrm{CO}_{3}(489 \mathrm{mg}, 1.5 \mathrm{mmol}), 5$-bromo- $m$-xylene $(185 \mathrm{mg}, 1 \mathrm{mmol})$, benzylic alcohol $(216 \mathrm{mg}, 2 \mathrm{mmol})$ with toluene $(2 \mathrm{~mL})$ as solvent for $18 \mathrm{~h}$ at $70{ }^{\circ} \mathrm{C}$. Chromatographic purification $\left(0.5 \%\right.$ ethyl acetate in hexane) provided $\mathbf{1 2} \mathbf{b}^{15}$ (colorless liquid, $203 \mathrm{mg}, 96 \%$ ). ${ }^{1} \mathrm{H}$ NMR (400 MHz, $\left.\mathrm{CDCl}_{3}\right) \delta$ 7.29-7.45 (m, 5H), $6.62(\mathrm{~s}, 3 \mathrm{H})$, $5.03(\mathrm{~s}, 2 \mathrm{H}), 2.29(\mathrm{~s}, 6 \mathrm{H}) .{ }^{13} \mathrm{C} \mathrm{NMR}\left(125 \mathrm{MHz}, \mathrm{CDCl}_{3}\right) \delta 158.8,139.2,137.2,128.5$, $127.8,127.4,122.7,112.5,69.7,21.4$.

\section{1-Butoxy-2,5-dimethylbenzene (12c)}

The general procedure was followed using $\mathrm{Pd}(\mathrm{OAc})_{2}(4.5 \mathrm{mg}, 0.02 \mathrm{mmol}), \mathbf{L 5}$ (9.4 mg, $0.024 \mathrm{mmol}), \mathrm{Cs}_{2} \mathrm{CO}_{3}(489 \mathrm{mg}, 1.5 \mathrm{mmol})$, bromo- $p$-xylene (185 mg, $\left.1 \mathrm{mmol}\right)$, butanol (148 mg, $2 \mathrm{mmol}$ ) with toluene $(2 \mathrm{~mL})$ as solvent for $18 \mathrm{~h}$ at $70{ }^{\circ} \mathrm{C}$. Chromatographic purification (hexane) provided $\mathbf{1 2} \mathrm{c}^{4}$ (colorless liquid, $141 \mathrm{mg}, 80 \%$ ). ${ }^{1} \mathrm{H}$ and ${ }^{13} \mathrm{C} \mathrm{NMR}$ data were consistent with those of the previously reported compound.

\section{1-Butoxy-4-methoxybenzene (12d)}


The general procedure was followed using $\mathrm{Pd}(\mathrm{OAc})_{2}(4.5 \mathrm{mg}, 0.02 \mathrm{mmol}), \mathbf{L 4}(11.5 \mathrm{mg}$, $0.024 \mathrm{mmol}), \mathrm{Cs}_{2} \mathrm{CO}_{3}$ (489 mg, $1.5 \mathrm{mmol}$ ), $p$-bromoanisole (187 mg, $1 \mathrm{mmol}$ ), 2-butanol (148 $\mathrm{mg}, 2 \mathrm{mmol})$ with toluene $(2 \mathrm{~mL})$ as solvent for $18 \mathrm{~h}$ at $70{ }^{\circ} \mathrm{C}$. Chromatographic purification ( $2 \%$ ethyl acetate in hexane) provided $\mathbf{1 2 d}^{4}$ (colorless liquid, $126 \mathrm{mg}, 70 \%$ ). ${ }^{1} \mathrm{H}$ and ${ }^{13} \mathrm{C}$ NMR data were consistent with those of the previously reported compound.

\section{1-Butoxy-2-methoxybenzene (12e)}

The general procedure was followed using $\mathrm{Pd}_{2}(\mathrm{dba})_{3}(9.2 \mathrm{mg}, 0.01 \mathrm{mmol})$ instead of $\mathrm{Pd}(\mathrm{OAc})_{2}, \mathbf{L 4}(11.5 \mathrm{mg}, 0.024 \mathrm{mmol}), \mathrm{Cs}_{2} \mathrm{CO}_{3}$ (489 mg, $\left.1.5 \mathrm{mmol}\right), o$-bromoanisole (187 $\mathrm{mg}, 1 \mathrm{mmol})$, 2-butanol (148 $\mathrm{mg}, 2 \mathrm{mmol})$ with toluene $(2 \mathrm{~mL})$ as solvent for $18 \mathrm{~h}$ at 70 ${ }^{\circ} \mathrm{C}$. Chromatographic purification (2\% ethyl acetate in hexane) provided $\mathbf{1 2}^{4}$ (colorless liquid, $131 \mathrm{mg}, 73 \%) .{ }^{1} \mathrm{H}$ and ${ }^{13} \mathrm{C}$ NMR data were consistent with those of the previously reported compound.

\section{3-Butoxybenzoic acid tert-butyl ester (12f)}

The general procedure was followed using $\mathrm{Pd}(\mathrm{OAc})_{2}(4.5 \mathrm{mg}, 0.02 \mathrm{mmol}), \mathbf{L 6}$ (10.7 $\mathrm{mg}$, $0.024 \mathrm{mmol}), \mathrm{Cs}_{2} \mathrm{CO}_{3}(489 \mathrm{mg}, 1.5 \mathrm{mmol}), 3$-bromobenzoic acid tert-butyl ester (257 mg, $1 \mathrm{mmol})$, butanol (148 $\mathrm{mg}, 2 \mathrm{mmol})$ with $\mathrm{Bu}_{3} \mathrm{~N}(2 \mathrm{~mL})$ as solvent for $18 \mathrm{~h}$ at $70{ }^{\circ} \mathrm{C}$. The filtrate was extracted with $10 \% \mathrm{HCl}(2 \times 35 \mathrm{~mL})$. Chromatographic purification $(1.5 \%$ ethyl acetate in hexane) provided $\mathbf{1 2 f} \mathbf{f}^{4}$ (colorless liquid, $223 \mathrm{mg}, 89 \%$ ). ${ }^{1} \mathrm{H}$ and ${ }^{13} \mathrm{C}$ NMR data were consistent with those of the previously reported compound. 


\section{Butoxybenzene (12g)}

The general procedure was followed. $\mathrm{Pd}(\mathrm{OAc})_{2}(4.5 \mathrm{mg}, 0.02 \mathrm{mmol}), \mathbf{L 6}(10.7 \mathrm{mg}, 0.024$ mmol), $\mathrm{Cs}_{2} \mathrm{CO}_{3}(489 \mathrm{mg}, 1.5 \mathrm{mmol})$, bromobenzene (157 mg, $\left.1 \mathrm{mmol}\right)$ and butanol (148 mg, $2 \mathrm{mmol})$ were used. $\mathrm{Bu}_{3} \mathrm{~N}(2 \mathrm{~mL})$ was utilized as a solvent. The reaction was performed at $70{ }^{\circ} \mathrm{C}$ for $18 \mathrm{~h}$. The filtrate was extracted with $10 \% \mathrm{HCl}(2 \times 35 \mathrm{~mL})$. The organic layer was isolated and the aqueous layer was extracted with diethyl ether. The combined organic extracts were dried over $\mathrm{MgSO}_{4}$ and the crude product was purified chromatographically (silica gel, pentane) to give after the solvent removal $\mathbf{1 2 g}^{16}$ as a colorless liquid (128 mg, $86 \%$ ). ${ }^{1} \mathrm{H}$ and ${ }^{13} \mathrm{C}$ NMR data were consistent with those of the commercially available compound.

\section{1-Butoxy-3,5-dimethylbenzene (12h)}

The general procedure was followed using $\operatorname{Pd}(\mathrm{OAc})_{2}(4.5 \mathrm{mg}, 0.02 \mathrm{mmol}), \mathbf{L 6}$ (10.7 mg, $0.024 \mathrm{mmol}), \mathrm{Cs}_{2} \mathrm{CO}_{3}(489 \mathrm{mg}, 1.5 \mathrm{mmol}), 1$-bromo-3-ethylbenzene (185 mg, $1 \mathrm{mmol}$ ), butanol (148 mg, $2 \mathrm{mmol})$ with $\mathrm{Bu}_{3} \mathrm{~N}(2 \mathrm{~mL})$ as solvent for $18 \mathrm{~h}$ at $70{ }^{\circ} \mathrm{C}$. The filtrate was extracted with $10 \% \mathrm{HCl}(2 \times 35 \mathrm{~mL})$. Chromatographic purification (hexane, followed by $2 \%$ ethyl acetate in hexane) provided $\mathbf{1 2} \mathbf{h}^{4}$ (colorless liquid, $162 \mathrm{mg}, 91 \%$ ). ${ }^{1} \mathrm{H}$ and ${ }^{13} \mathrm{C}$ NMR data were consistent with those of the previously reported compound.

\section{1,3-Dimethyl-5-prop-1-ynyloxybenzene (12i)}

The general procedure was followed using $\mathrm{Pd}(\mathrm{OAc})_{2}(4.5 \mathrm{mg}, 0.02 \mathrm{mmol}), \mathbf{L 6}$ (10.7 mg, $0.024 \mathrm{mmol}), \mathrm{Cs}_{2} \mathrm{CO}_{3}(489 \mathrm{mg}, 1.5 \mathrm{mmol}), 5$-bromo- $m$-xylene $(185 \mathrm{mg}, 1 \mathrm{mmol})$, 
propyn-1-ol (140 mg, $2 \mathrm{mmol})$. The solution of the alcohol in $1 \mathrm{~mL}$ of toluene was added under argon over $10 \mathrm{~h}$ to the stirred at $70{ }^{\circ} \mathrm{C}$ reaction mixture in $1 \mathrm{~mL}$ of toluene via syringe with the help of a syringe pump. Chromatographic purification $(0.5 \%$ ethyl acetate in hexane) provided $\mathbf{1 2} \mathbf{i}^{17}$ (colorless liquid, $\left.157 \mathrm{mg}, 90 \%\right) .{ }^{1} \mathrm{H}$ NMR (400 MHz, $\left.\mathrm{CDCl}_{3}\right) \delta 6.62(\mathrm{~s}, 1 \mathrm{H}), 6.58(\mathrm{~s}, 2 \mathrm{H}), 4.60(\mathrm{q}, 2 \mathrm{H}, \mathrm{J}=2.3 \mathrm{~Hz}), 2.28(\mathrm{~s}, 6 \mathrm{H}), 1.86(\mathrm{t}, 3 \mathrm{H})$. ${ }^{13} \mathrm{C}$ NMR $\left(125 \mathrm{MHz}, \mathrm{CDCl}_{3}\right) \delta 157.8,139.1,122.9,112.4,83.4,74.2,56.1,21.4,3.7$.

\section{1,3-Dimethyl-5-(3-methylbut-2-enyloxy)-benzene (12j)}

The general procedure was followed using $\mathrm{Pd}(\mathrm{OAc})_{2}(4.5 \mathrm{mg}, 0.02 \mathrm{mmol}), \mathbf{L 6}$ (10.7 mg, $0.024 \mathrm{mmol}), \mathrm{Cs}_{2} \mathrm{CO}_{3}$ (489 mg, $\left.1.5 \mathrm{mmol}\right), 5$-bromo-m-xylene (185 mg, $\left.1 \mathrm{mmol}\right), 3-$ methylbut-2-en-1-ol (172 mg, $2 \mathrm{mmol})$ with toluene $(2 \mathrm{~mL})$ as solvent for $18 \mathrm{~h}$ at $50{ }^{\circ} \mathrm{C}$. Chromatographic purification (1\% ethyl acetate in hexane) provided $\mathbf{1 2 \mathbf { j }}$ (colorless liquid, $159 \mathrm{mg}, 84 \%) .{ }^{1} \mathrm{H}$ NMR $\left(300 \mathrm{MHz}, \mathrm{CDCl}_{3}\right) \delta 6.60(\mathrm{~s}, 1 \mathrm{H}), 6.57$ (s, 2H), 5.60$5.42(\mathrm{~m}, 1 \mathrm{H}), 4.49(\mathrm{~d}, J=6.6 \mathrm{~Hz}, 2 \mathrm{H}), 2.31(\mathrm{~s}, 6 \mathrm{H}), 1.82(\mathrm{~s}, 3 \mathrm{H}), 1.76(\mathrm{~s}, 3 \mathrm{H}) ;{ }^{31} \mathrm{C} \mathrm{NMR}$ $\left(75 \mathrm{MHz}, \mathrm{CDCl}_{3}\right) \delta 158.9,139.2,138.0,122.4,119.9,112.5,64.7,26.2,21.8,18.5 ; \mathrm{IR}$ (neat, $\mathrm{cm}^{-1}$ ) 2917, 1594, 1293, 1154, 1055, 826, 687. Anal. Calcd for $\mathrm{C}_{13} \mathrm{H}_{18} \mathrm{O}: \mathrm{C}, 82.06$; H, 9.53. Found: C, 81.91; H, 9.61.

\section{4-(3,5-Dimethylphenoxy)-butan-2-ol (12k)}

The general procedure was followed using $\mathrm{Pd}(\mathrm{OAc})_{2}(11.2 \mathrm{mg}, 0.05 \mathrm{mmol}), \mathbf{L 4}(28.8 \mathrm{mg}$, $0.06 \mathrm{mmol}), \mathrm{Cs}_{2} \mathrm{CO}_{3}(489 \mathrm{mg}, 1.5 \mathrm{mmol}), 5$-bromo- $m$-xylene $(185 \mathrm{mg}, 1 \mathrm{mmol})$ and $1,3-$ 
butandiol (108 mg, $2 \mathrm{mmol})$ with toluene $(2 \mathrm{~mL})$ as solvent for $24 \mathrm{~h}$ at $70{ }^{\circ} \mathrm{C}$. Chromatographic purification (20\% ethyl acetate in hexane) provided a yellowish oil, which was found by TLC and NMR to contain the coupling product contaminated by a small amount of $\mathbf{L 4}$. To remove $\mathbf{L} \mathbf{4}$, the oil was dissolved in $3 \mathrm{~mL}$ of diethyl ether, $\mathrm{HBF}_{4}$ monoetherate ( $0.12 \mathrm{mmol}, 23 \mathrm{mg}$ of $85 \%$ solution) was added, the solvent was removed and the residue was filtered through a short plug of silica gel (25\% ethyl acetate in hexane), giving 12k (colorless oil, $0.128 \mathrm{~g}, 66 \%) .{ }^{1} \mathrm{H}$ NMR $\left(400 \mathrm{MHz}, \mathrm{CDCl}_{3}\right) \delta 6.60(\mathrm{~s}$, 1H), $6.54(\mathrm{~s}, 2 \mathrm{H}), 4.02-4.15(\mathrm{~m}, 3 \mathrm{H}), 2.36-2.41$ (br. s, 1H), $2.28(\mathrm{~s}, 6 \mathrm{H}), 1.87-1.92(\mathrm{~m}$, 2H), $1.25(\mathrm{~d}, 3 \mathrm{H}, \mathrm{J}=6.2 \mathrm{~Hz}) .{ }^{13} \mathrm{C} \mathrm{NMR}\left(100 \mathrm{MHz}, \mathrm{CDCl}_{3}\right) \delta 158.7,139.1,122.8,112.1$, 66.2, 65.7, 38.0, 23.3, 21.4. IR (neat, $\left.\mathrm{cm}^{-1}\right)$ 3381, 2967, 1740, 1595, 1469, 1324, 1156, 830, 689. HRMS (ESI) calcd for $\mathrm{C}_{12} \mathrm{H}_{18} \mathrm{O}_{2}\left[\mathrm{M}+\mathrm{Na}^{+}\right]$: 217.1199. Found: 217.1195 
${ }^{1} \mathrm{H}$ NMR spectrum of $\mathbf{1 2 k}$

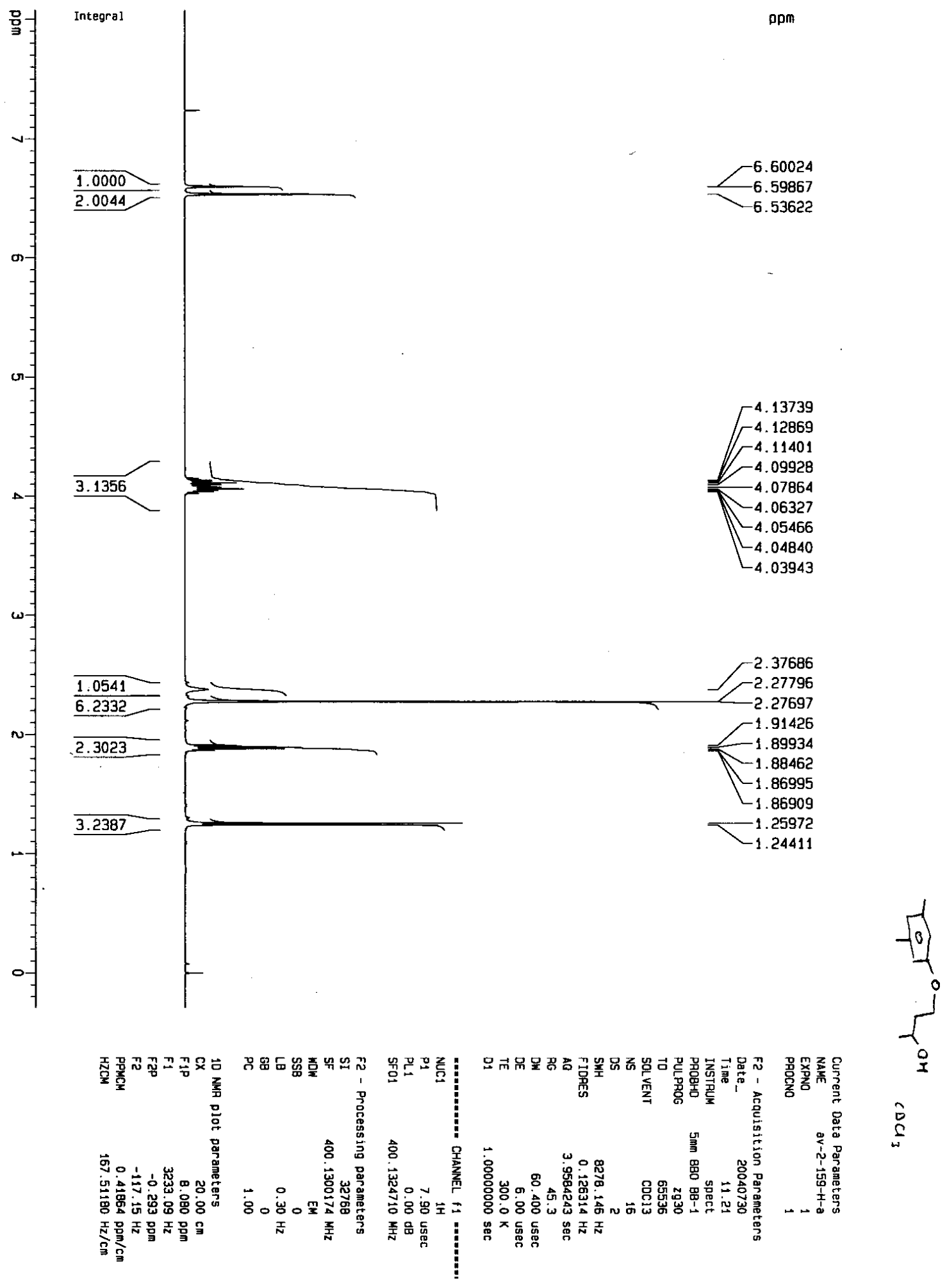




\section{1-Bromo-3-iso-propoxybenzene (7)}

The general procedure ${ }^{18}$ for the $\mathrm{Cu}$-catalyzed intermolecular coupling of alcohols with aryl iodides was followed. An oven-dried Schlenk tube was charged with CuI (191 mg, 1 mmol), 1,10-phenanthroline (360 mg, $2 \mathrm{mmol})$ and $\mathrm{Cs}_{2} \mathrm{CO}_{3}(6.52 \mathrm{~g}, 20 \mathrm{mmol})$. The solution of 1-bromo-3-iodobenzene $(2.83 \mathrm{~g}, 10 \mathrm{mmol})$ in isopropanol $(10 \mathrm{~mL})$ was added. The Schlenk tube was sealed with Teflon screw cap and placed in an oil bath $\left(110^{\circ} \mathrm{C}\right)$ for $24 \mathrm{~h}$. After the reaction mixture was allowed to cool to room temperature, it was filtered through a layer of silica gel (diethyl ether). The solution was concentrated, filtered through a short plug of silica gel (5\% ethyl acetate in hexane). The solvent was removed to provide $7^{19}$ (colorless oil, $1.742 \mathrm{~g}, 81 \%$ ). ${ }^{1} \mathrm{H}$ and ${ }^{13} \mathrm{C}$ NMR data were consistent with those of the commercially available compound.

\section{1-(1,3-Dimethylbut-2-enyloxy)-3-iso-propoxybenzene (8)}

The general procedure for the Pd-catalyzed intermolecular coupling of alcohols with aryl halides was followed using $\operatorname{Pd}(\mathrm{OAc})_{2}(6.7 \mathrm{mg}, 0.03 \mathrm{mmol}), \mathbf{L 1 0}(17.1 \mathrm{mg}, 0.036 \mathrm{mmol})$, $\mathrm{Cs}_{2} \mathrm{CO}_{3}$ (489 mg, $\left.1.5 \mathrm{mmol}\right), 7$ (215 mg, $1 \mathrm{mmol}$ ), 4-methylpent-3-en-2-ol (200 mg, 2 mmol) with $\mathrm{Bu}_{3} \mathrm{~N}(2 \mathrm{~mL})$ as solvent for $18 \mathrm{~h}$ at $50{ }^{\circ} \mathrm{C}$. A mixture of $10 \% \mathrm{HCl}(5 \mathrm{~mL})$ and water $(15 \mathrm{~mL})$ was used for the extraction. Chromatographic purification (2\% ethyl acetate in hexane) provided 8 (colorless liquid, $195 \mathrm{mg}, 83 \%$ ). ${ }^{1} \mathrm{H}$ NMR (400 MHz, $\left.\mathrm{CDCl}_{3}\right) \delta 7.11(\mathrm{t}, 1 \mathrm{H}, \mathrm{J}=8.0 \mathrm{~Hz}), 6.42-6.49(\mathrm{~m}, 3 \mathrm{H})$, 5.20-5.26 (m, 1H), 4.93-5.00 (m, 1H), 4.49 (septet, 1H, J = 6.1 Hz), $1.72(\mathrm{~s}, 6 \mathrm{H}), 1.36(\mathrm{~d}, 3 \mathrm{H}, \mathrm{J}=6.2 \mathrm{~Hz}), 1.32(\mathrm{~d}, 6 \mathrm{H}, \mathrm{J}=$ 
$6.0 \mathrm{~Hz}) .{ }^{13} \mathrm{C}$ NMR $\left(100 \mathrm{MHz}, \mathrm{CDCl}_{3}\right) \delta 159.3,158.9,134.1,129.6,127.0,108.2,107.8$, 103.7, 71.1, 69.7, 25.6, 22.1, 22.0, 21.3, 18.2. IR (neat, $\left.\mathrm{cm}^{-1}\right)$ 2977, 1588, 1489, 1373, 1282, 1145, 1006, 836, 762, 688. Anal. Calcd for $\mathrm{C}_{15} \mathrm{H}_{22} \mathrm{O}_{2}$ : C, 76.88; H, 9.46. Found: C, 76.61; H, 9.51.

\section{Synthesis of ${ }^{18} \mathrm{O}$ - labeled 1-phenylethanol.}

To the $\mathrm{CH}_{2} \mathrm{Cl}_{2}$ solution of acetophenone $(1.2 \mathrm{~g}, 10 \mathrm{mmol})$ and $\mathrm{CH}_{3} \mathrm{SO}_{2} \mathrm{OH}(1.056 \mathrm{~g}, 11$ mmol) $\mathrm{H}_{2} \mathrm{O}^{18}\left(95 \%{ }^{18} \mathrm{O}, 200 \mathrm{mg}, 10 \mathrm{mmol}\right)$ was added and the mixture was stirred at room temperature for $15 \mathrm{~h}$. Then it was filtered through a plug of silica gel $\left(\mathrm{CH}_{2} \mathrm{Cl}_{2}\right)$. The solvent was removed to give ${ }^{18} \mathrm{O}$-enriched acetophenone $(1.149 \mathrm{~g})$. This was dissolved in dry THF, $\mathrm{NaBH}_{4}\left(361 \mathrm{mg}, 9.496 \mathrm{mmol}\right.$ ) was added and the mixture was stirred under $\mathrm{N}_{2}$ for $3 \mathrm{~h}$ at $70{ }^{\circ} \mathrm{C}$. Then it was cooled to room temperature, water $(20 \mathrm{~mL})$ was added, followed by $10 \% \mathrm{HCl}$. The mixture was transferred to a separatory funnel, shaken, the organic layer was isolated and the aqueous layer was extracted with diethyl ether ( 2 x 25 $\mathrm{mL}$ ). The combined organic layers were united, dried over $\mathrm{MgSO}_{4}$. The solvent was evaporated and the crude product was purified chromatographically (silica gel, $20 \%$ ethyl acetate in hexane) to give after the solvent removal $0.856 \mathrm{~g}$ of the product (73\%). The isotopic composition was determined by MS analysis $\left(40 \%{ }^{18} \mathrm{O}\right)$.

\section{Coupling of 5-bromo-m-xylene with ${ }^{18} \mathrm{O}-1$-phenylethanol.}

The general procedure for the Pd-catalyzed intermolecular coupling of alcohols with aryl halides was followed using $\mathrm{Pd}(\mathrm{OAc})_{2}(2.2 \mathrm{mg}, 0.01 \mathrm{mmol}), \mathbf{L 4}(5.8 \mathrm{mg}, 0.012 \mathrm{mmol})$, 
$\mathrm{Cs}_{2} \mathrm{CO}_{3}{ }^{20}$ (245 mg, $\left.0.75 \mathrm{mmol}\right)$, 5-bromo-m-xylene (93 mg, $\left.0.5 \mathrm{mmol}\right),{ }^{18} \mathrm{O}-1-$ phenylethanol $\left(40 \%{ }^{18} \mathrm{O}, 123 \mathrm{mg}, 1 \mathrm{mmol}\right)$ with toluene $(1 \mathrm{~mL})$ as solvent for $24 \mathrm{~h}$ at 90 ${ }^{\circ} \mathrm{C}$. Chromatographic purification (1\% ethyl acetate in hexane) provided 5 (8 $\left.\mathrm{mg}, 8 \%\right), 4$ (51 $\mathrm{mg}, 45 \%)$, (rac)-2f (18 $\mathrm{mg}, 8 \%)$. The isotopic composition of $\mathbf{4}$ and $\mathbf{2 f}$ was determined by MS analysis. The latter contained $40 \%{ }^{18} \mathrm{O}$, the former showed no ${ }^{18} \mathrm{O}$ enrichment.

\footnotetext{
${ }^{1}$ Torraca, K. E.; Kuwabe, S.; Buchwald, S. L. J. Am. Chem. Soc. 2000, 122, 12907.

${ }^{2}$ Aranyos, A.; Old, D. W.; Kiyomori, A.; Wolfe, J. P.; Sadighi, J. P.; Buchwald, S. L. J. Am. Chem. Soc. 1999, 121, 4369 .

${ }^{3}$ Huang, X.; Anderson, K. W.; Zim, D.; Jiang, L.; Klapars, A.; Buchwald, S. L. J. Am. Chem. Soc. 2003, 125, 6653.

${ }^{4}$ Torraca, K. E.; Huang, X.; Parrish, C; Buchwald, S. L. J. Am. Chem. Soc. 2001, 123, 10770.

${ }^{5}$ Kajigaeshi, S.; Kakinami, T.; Moriwaki, M.; Tanaka, T.; Fujisaki, S.; Okamoto, T. Bull. Chem. Soc. Jpn. 1989, 62, 439.

${ }^{6}$ Smith, M. J. Am. Chem. Soc. 1933, 55, 1676.

${ }^{7}$ Adachi T. Yuki Gosei Kagaku Kyokaishi 1976, 34, 666.

${ }^{8}$ Hayashi, T.; Hayashizaki, K.; Kiyoi, T.; Ito, Y. J. Am. Chem. Soc. 1988, 110, 8153.

${ }^{9}$ Hayashi, T.; Kamikawa, T. Tetrahedron Lett. 1997, 38, 7087.

${ }^{10}$ Herwig, J.; Keim, W.; Inorg. Chim. Acta 1994, 222, 381.

${ }^{11}$ v. Braun; H.; Chem. Ber. 1926, 59, 2011.

${ }^{12}$ Lei, A.; Zhang, X.; Tetrahedron Lett. 2002, 43, 2525.

${ }^{13}$ Manku, S.; Wang, F.; Hall, D. G. J. Comb. Chem. 2003, 5, 379.

${ }^{14}$ Fresneda, P. M.; Molina, P.; Bleda, J. A. Tetrahedron 2001, 57, 2355.

${ }^{15}$ Renga, J. M.; Wang, P.-C. Synth. Commun. 1984, 14, 69.

${ }^{16}$ Commercially available from Aldrich $(14,234-4)$

${ }^{17}$ Sarcevic, N.; Zsindely, J.; Schmid, H. Helv. Chim. Acta 1973, 56, 1457.

${ }^{18}$ Wolter, M.; Nordmann, G.; Job, G. E.; Buchwald, S. L. Org. Lett. 2002, 4, 973.
} 
${ }^{19}$ Commercially available from Aldrich $(51,550-7)$

${ }^{20}$ weighed and added into the Schlenk tube in the glove box 